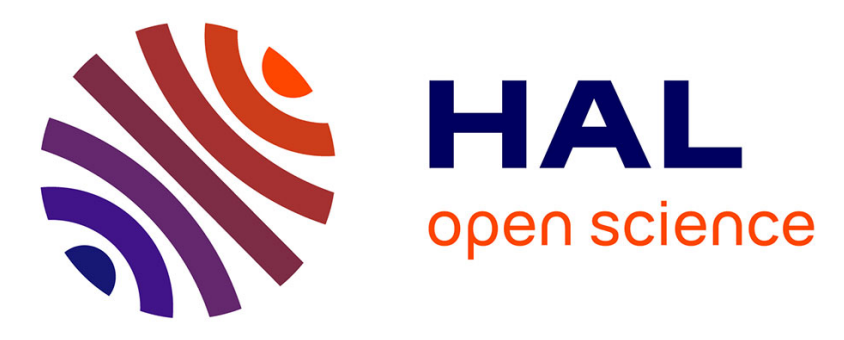

\title{
Modelling with stakeholders to integrate biodiversity into land-use planning - Lessons learned in Réunion Island (Western Indian Ocean)
}

Erwann Lagabrielle, Aurélie Botta, Williams Daré, Daniel David, Sigrid Aubert, Christo Fabricius

\section{To cite this version:}

Erwann Lagabrielle, Aurélie Botta, Williams Daré, Daniel David, Sigrid Aubert, et al.. Modelling with stakeholders to integrate biodiversity into land-use planning - Lessons learned in Réunion Island (Western Indian Ocean). Environmental Modelling and Software, 2010, 25 (11), pp.1413-1427. cirad00843325

\section{HAL Id: cirad-00843325 \\ http://hal.cirad.fr/cirad-00843325}

Submitted on 11 Jul 2013

HAL is a multi-disciplinary open access archive for the deposit and dissemination of scientific research documents, whether they are published or not. The documents may come from teaching and research institutions in France or abroad, or from public or private research centers.
L'archive ouverte pluridisciplinaire HAL, est destinée au dépôt et à la diffusion de documents scientifiques de niveau recherche, publiés ou non, émanant des établissements d'enseignement et de recherche français ou étrangers, des laboratoires publics ou privés. 


\section{Elsevier Editorial System(tm) for Environmental Modelling \& Software}

Manuscript Draft

Manuscript Number: ENVSOFT-D-08-00001R4

Title: Modelling with stakeholders to integrate biodiversity into land-use planning - Lessons learned in Réunion Island (Western Indian Ocean)

Article Type: Special Issue: Model. with Stakeholders

Keywords: Biodiversity, Land-use management, Conservation planning, Participatory modelling, Stakeholder, Multi-Agent System, Réunion Island

Corresponding Author: Mr Lagabrielle Erwann, Ph.D

Corresponding Author's Institution: Cirad

First Author: Lagabrielle Erwann, Ph.D

Order of Authors: Lagabrielle Erwann, Ph.D; Botta Aurélie; Daré William's; David Daniel; Aubert Sigrid; Fabricius Christo, Pr.

Abstract: This paper considers participatory modelling to integrate biodiversity conservation into land use planning and to facilitate the incorporation of ecological knowledge into public decision making for spatial planning. Réunion Island has experienced rapid urban and agricultural expansion, which threaten its unique biodiversity. In this context, we designed three participatory modelling sequences, involving overall 24 multidisciplinary researchers and stakeholders. The sequences aimed 1) to map land-use and biodiversity, 2) to develop a conservation plan following systematic conservation planning principles using a spatial optimization tool (MARXAN) and 3) to simulate coupled landuse/conservation scenarios using a multi-agent system (MAS). The conservation plan confirms that priority areas for biodiversity protection are located on the coast where rapid land-use changes occur. Nevertheless, stakeholders from the urban and agricultural sector didn't participate to this sequence. Indeed, conservation planning tools are useful to locate conservation priorities but they have to be designed with stakeholders to be accepted as negotiation tool. Besides, the researchers engaged in this second sequence were perceived as conservation stakeholders rather than holders of scientific knowledge. In the third sequence, the researchers involved adopted the stance of facilitating the elicitation of each stake and gathered trust from stakeholders. Overall, we conclude that the participatory development of land-use simulation models should be promoted to explore alternative scenarios for biodiversity conservation with stakeholders. In a situation of land-use conflict, a gradual and sequential participatory modelling approach should be implemented to fit into public decisionmaking processes. 
Erwann Lagabrielle (Dr.)

January 30, 2009

Conservation Planning Research

Nelson Mandela Metropolitan University / Botany department

Personal postal address:

49 Netford Rd

Bluff, Durban, 4052

South Africa

Email: erwann.lagabrielle@gmail.com

Mobile: 0027 (0)71 4600858

Skype: erwann.lagabrielle

To:

Tony Jakeman

Editor-in-Chief

Environmental Modelling \& Software

Dear Editors, Dear Reviewers,

Attached to this letter is the last version of our paper, entitled "Modelling with stakeholders to integrate biodiversity into land-use planning - Lessons learned in Réunion Island".

We did the minor changes you requested. The following section describes our response to the requested minor revision.

Thank you and we look forward to hearing from you.

With best regards,

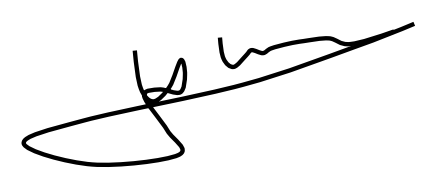

Erwann Lagabrielle 


\section{Response to detailed comments:}

To facilitate the correction checking, our answers to comments are in italic.

Line 34: what does " however this sequence never reached the stakeholders audience » means?

We corrected it to: "Nevertheless, stakeholders from the urban and agricultural sector didn't participate to this sequence."

Line 182 "," instead of ";"

We corrected it to ","

Line 305: were are the 21 habitats in table 1?

We completed the sentence as follows "We mapped a system of 44 land-use and habitat classes, including 21 pristine habitats grouped into 7 broader altitudinal groups (Table 1)."

Line 462 is not it table 2 instead of table $1 ?$

Yes, we corrected it to "Table 2"

Line 632: How would I see the $50 \%$ on figure 7 ?

We added the following sentence: "Indeed, the exponential shape of the unachieved demand for agricultural land on Figure 7 is due to the concomitant conversion of agricultural land by urbanisation in the lowlands." 
1 Title:

2 Modelling with stakeholders to integrate biodiversity into land-use planning -

3 Lessons learned in Réunion Island (Western Indian Ocean)

4 Authors:

5 Erwann Lagabrielle ${ }_{1,2}{ }^{*}$, Aurélie Botta 3 , William's Daré 4 , Daniel David ${ }_{5}$, Sigrid Aubert 6 6, Christo Fabricius 1

7 Affiliations:

$8{ }^{1}$ Nelson Mandela Metropolitan University - Saasveld Campus - Private Bag X6531 9 George 6530 - South Africa

102 CIRAD, Université de la Réunion, UMR PVBMT, 7 chemin de I'IRAT, Ligne

11 Paradis, 97410, Saint-Pierre, France

$12{ }^{3}$ CIRAD, UPR GREEN, Campus International de Baillarguet - TA C- 47/F - 34398

13 Montpellier Cedex 5 - France

$14{ }^{4}$ CIRAD, UPR GREEN, Pôle REAGIR, Station de La Bretagne, BP 20, 97408 Saint15 Denis Messagerie Cedex 9 - France

$16{ }^{5}$ Université de la Réunion, EA2525 LIM IREMIA, 2 rue Joseph Wetzel, 97490,

17 Sainte-Clotilde, La Réunion, France

$18{ }^{6}$ CIRAD, UPR GREEN, Ampandrianomby - B.P. 853 - 99 Antananarivo -

19 Madagascar

21 E-mail authors: erwann.lagabrielle@gmail.com

22 Fax authors: $+27(0) 866140137$ 


\begin{abstract}
24 Abstract:
Key words:

This paper considers participatory modelling to integrate biodiversity conservation into land use planning and to facilitate the incorporation of ecological knowledge into public decision making for spatial planning. Réunion Island has experienced rapid urban and agricultural expansion, which threaten its unique biodiversity. In this context, we designed three participatory modelling sequences, involving overall 24 multidisciplinary researchers and stakeholders. The sequences aimed 1) to map land-use and biodiversity, 2) to develop a conservation plan following systematic conservation planning principles using a spatial optimization tool (MARXAN) and 3) to simulate coupled land-use/conservation scenarios using a multi-agent system (MAS). The conservation plan confirms that priority areas for biodiversity protection are located on the coast where rapid land-use changes occur. Nevertheless, stakeholders from the urban and agricultural sector didn't participate to this sequence. Indeed, conservation planning tools are useful to locate conservation priorities but they have to be designed with stakeholders to be accepted as negotiation tool. Besides, the researchers engaged in this second sequence were perceived as conservation stakeholders rather than holders of scientific knowledge. In the third sequence, the researchers involved adopted the stance of facilitating the elicitation of each stake and gathered trust from stakeholders. Overall, we conclude that the participatory development of land-use simulation models should be promoted to explore alternative scenarios for biodiversity conservation with stakeholders. In a situation of land-use conflict, a gradual and sequential participatory modelling approach should be implemented to fit into public decision-making processes.

Biodiversity, Land-use management, Conservation planning, Participatory modelling, Stakeholder, Multi-Agent System, Réunion Island
\end{abstract}




\section{Introduction}

Since the mid $20^{\text {th }}$ Century, urbanisation and agricultural expansion have accelerated all around the world. These trends threaten biodiversity and renewable resources (Jenkins, 2003, Wilson and Peter, 1988), thereby stressing the need for linking land-use planning and conservation. Land-use planning guides the organization of a spatial environment to meet the demands of a society (Ligtenberg et al., 2004, Verburg et al., 2004). However, land-use plans only recently started to integrate biodiversity conservation as an explicit goal (Margules and Pressey, 2000, Driver et al., 2003). Conservation planning, a branch of applied conservation science, has been specifically developed to integrate biodiversity conservation and land-use planning within a single framework. Nevertheless, in practice, the two remain disjointed (Cowling, 2005). In this study, we analyse the association of three participatory modelling sequences for integrating conservation into land-use planning.

Conservation planning aims to promote the persistence of 'living landscapes' that integrate biodiversity requirements (Driver et al., 2003, Arendt, 2003). It is theoretically based on a spatially explicit understanding of complex ecological systems and their interactions with social systems (Termorshuizen et al., 2007, Gunderson and Holling, 2002). Conservation planning approaches range on a continuum from opportunistic to systematic planning approaches (Maruani and AmitCohen, 2007). These methods focus on habitats, species and ecological processes.

The Systematic Conservation Planning (SCP) approach developed by Margules and Pressey (2000) represents a key step towards a spatially explicit, target-driven planning process for biodiversity conservation. SCP aims to achieve a set of quantitative conservation targets (e.g. $20 \%$ of each habitat in a region) through the identification of a network of priority areas for conservation, while minimising conflicts with other land-use (e.g. urbanisation or agriculture) using specialised GIS software (Moilanen and Kujala, 2008, Ball and Possingham, 2000). Few studies tested the use of such conservation planning software in a large participatory framework involving researchers and stakeholders.

In the perspective of sustainable development, a participatory approach to conservation planning must address the behaviour of the social groups involved in land management (Mathevet et al., 2003). The participation of stakeholders is vital for the development and implementation of conservation and land-use plans (Castella et al., 2005, Brown, 2003). As Mathevet et al. (2003) point out, the placement of conservation areas is usually determined by ad hoc opportunities (e.g. cheap land), low agricultural potential (e.g. mountainous areas), and moreover, political will. Conservation planning thus requires the combination of scientific knowledge with an understanding of the stakeholders involved in the planning process (Knight et al., 2006).

Bousquet et al. (1999) propose an approach based on the development of models together with stakeholders and researchers to simulate land management scenarios: the companion modelling approach (ComMod). Within the ComMod approach, the collaborative development of simulation models is a learning process that leads the participants (including researchers) to explain and share opinions regarding management options (Souchère et al., 2009, Barreteau et al., 2003). In this approach, the most important is less the solution but the process leading to it. Many applications developed under the ComMod theoretical framework are using 
Multi-Agent Systems (MAS) as simulation tools to implement their models. A MAS can be defined as a set of agents that interact in a common environment, able to modify their attributes and their environment (Ferrand, 1997). In environmental science, agents are often humans interacting with resources distributed in a landscape. MAS may increase understanding of complex coupled social-ecological systems (Acevedo et al., 2007), more particularly in the context of land-use planning (Parker et al, 2002, Etienne et al. 2003, Bousquet and Le Page, 2004, Schreinemachers and Berger, 2006) and biodiversity planning (Vejpas et al., 2005)

This article is divided into eight sections. The first section presents the studied site and its main challenges in terms of land-use and conservation planning. The second section summarizes the organisation of the experiment as a whole, whereas the three following sections are focalizing on each of the participatory modelling sequences. We discuss the results of the experiments, their impacts and the participation of stakeholders and researchers in the following section. And finally, we conclude on the implications of the study for conservation and land-use planning methodology.

\section{Context and objectives}

\subsection{Spatial planning challenges}

The study site for this application is the Réunion Island, a volcanic Island of 2512 $\mathrm{km}^{2}$ in the Western Indian Ocean (Figure 1). Together with Mauritius and Rodrigues, it forms the Mascarene archipelago. Réunion Island is a French overseas department.

Elevations range from sea level to $3070 \mathrm{~m}$. Land-use is organised into urban and agricultural belts in the so-called lowlands $(<2000 \mathrm{~m})$, and pristine vegetation in the uplands. At present, more than $80 \%$ of the 802000 inhabitants (INSEE, 2009) live on the coastal fringe where most of the socio-economic activities are concentrated. Population increased of $1.5 \%$ per year since 2000 and it is predicted to reach 1 million inhabitants in 2030 (INSEE, 2009).

\section{Figure 1}

The economy of the island has traditionally been based on crop industry, mainly sugarcane. Since the 1980s, the French government has been pushing the development of a tourist industry to alleviate unemployment which currently amounts to more than $40 \%$ of the labour force.

The economy remains highly dependent on external incomes. Since the 1990s, as an outermost region of the European Union, Réunion Island has beneficiated from European funds for development. This has caused dramatic socio-economic changes that have impacted the landscapes. For instance, urban areas in Réunion Island sprawled out by 157\% from 1989 to 2002 (Lagabrielle et al., 2007).

Concomitantly to the economic development, available land becomes a rare resource. Landscapes are now expected to fulfil multiple functions and this causes 
conflicts among stakeholders about land-use planning and management (Van Der Valk, 2002). As the study started, the agricultural sector was asking for roughly 6000 extra hectare of land (Département de la Réunion 2006).

Future challenges for land-use planning in Réunion Island are the control of urban sprawl, the adaptation of infrastructures (particularly roads and water supply devices), the development of public transport, the protection of agricultural lands and biodiversity conservation. Those challenges are listed in the territorial diagnostic produced by the regional council (Conseil Régional de la Réunion, 2009).

Legally, a regional development plan ("Schéma d'Aménagement Régional": hereafter referred as SAR) rules the allocation of land-use for the whole island, the organisation and the implementation of regional infrastructures including the main roads. Municipal and inter-municipal land-use plans and other regional sector plans (agricultural, industrial, etc.) must be compatible with it. The SAR developed in 1995 was under revision as this study was done. A major objective of the 1995 SAR was to control urban sprawl. To this purpose, it allocated an urbanisation quota to each of the 24 municipalities. Most municipalities exceeded by far their quota, causing tensions between the agricultural and the urban sector. This same objective is therefore still valid for the new SAR.

\subsection{Pressures on biodiversity and conservation measures}

Réunion Island has long been recognised as a global priority for conservation owing to its vulnerability and its high concentration of endemic taxa, especially of plants. Sixty five per cent of the island's 600 species of flowering plants species are endemic (Cadet, 1980). This island lies within the Madagascar biodiversity hotspot (Mittermeier et al., 2005) and a marine biodiversity hotspot (Roberts et al., 2002). Since European occupation in 1665, the pristine vegetation cover in the lowlands has been almost fully converted, except on harsh slopes (Gigord et al., 1999, Strasberg et al., 2005). Increasing anthropogenic pressure has already led to the extinction of 30 of the 45 vertebrates species (Cheke, 1987).

Habitat conversion by urbanisation or agriculture, and habitat degradation by invasive alien species (for instance Clidemia hirta and Acacia mearnsii among 62 species considered as highly invasive) are the main threats to native biodiversity (Baret et al., 2006). $90 \%$ of the lowland habitats have been cleared or replaced by alien vegetation (Strasberg et al, 2005) (Table 1). Urbanisation pressure is extremely high on remnant pristine habitats in the lowlands, while native forest clearing for cattle breeding is a major threat to biodiversity in the uplands.

\section{Table 1}

Because of its steep land environment, one third of the island is still covered by native vegetation (Table 1), whereas other islands of the Mascarene archipelago almost lost their pristine vegetation cover (Strasberg et al., 2005). Therefore, Réunion Island is now responsible for the conservation of terrestrial biodiversity in the whole Mascarene region. 
Since the creation of a National Park in 2007, 43\% of the island's surface is protected within statutory reserves (i.e. areas specifically dedicated to biodiversity conservation). The distribution of the protected areas network is biased toward the uplands: the mean altitude of protected areas is $1306 \mathrm{~m}$ versus $873 \mathrm{~m}$ for the whole island. This lack of protection in the lowlands is a consequence of a combination of factors including the persistence of fewer pristine lowland habitats and higher pressure from other activity sectors (urbanisation and agriculture). Consequently, the future of biodiversity in Réunion Island now depends straight on land-use planning in the lowlands.

\subsection{Study objectives}

In line with the current and future development challenges in Réunion Island, the operational objectives of this study were i) to identify priority areas for conservation, ii) to provide guidelines for implementing conservation actions outside existing reserves while dealing with increasing pressuring factors in the lowlands; iii) to "accompany" the conservation sector to negotiate land-use planning and decisionmaking, more particularly in relation to the new regional land-use plan and the management plan of the National Park, and iv) to explore alternative scenarios for land-use and conservation planning. Alongside with those objectives, the overall goal was to test different approaches to bridge the scientific and operational communities by bringing multidisciplinary scientists and stakeholders to collaborate around the participatory development of spatial models for land-use and conservation planning.

\section{Development and organisation of the participatory modelling sequences}

This section briefly presents the organisation, objectives and participants of the participatory modelling sequence. Basically a participatory modelling sequence consists in building a model (in our case a map or a computer tool) and using it to perform a diagnostic or to simulate scenarios interactively with stakeholders. Those stakeholders are defined as individuals, groups or organisations that can affect or be affected by the implementation of the spatial plan. In our study, those stakeholders belong to three activity sectors: agriculture, conservation and urbanisation. In the following text, the term "regional" means the whole Réunion Island.

- The objective of the first sequence (hereafter S1) was to map biodiversity and land-use using a Geographic Information System (GIS). A first group of participants specialized in conservation issues (hereafter $\mathrm{G} 1$ ) mapped biodiversity and a second group (G2) mapped the land-use. G1 and G2 had a common core of scientist participants. G1 was a team of 10 persons, who were mainly scientists (geographer, anthropologist, agronomist, modeller and ecologist), but also staff of the National Parks authority. G1 was primarily interested in assessing biodiversity representation within the current network of protected areas. G2 gathered a multidisciplinary team of 11 researchers (modellers, ecologist, sociologist, anthropologist, urban and rural geographers and computer scientists) and 6 members of extension and support services staff for rural development.

- The second sequence (S2) aimed to identify a complementary network of priority areas for biodiversity conservation using a spatial optimization GIS tool (MARXAN). It was done by the G1 group. 
- The third sequence (S3) aimed to support the SAR revision by developing a ComMod approach for land-use foresight (Botta et al. 2009). We used an agent based model developed in two steps. A first prototype was built by the $\mathrm{G} 2$ group. It was then adapted by a second team including part of G2 (6 persons among which 4 researchers) and the group in charge of the SAR revision (4 persons: coordinator, urban planner, and 2 engineers specialized in environment and GIS). Hereafter we refer to this group as $\mathrm{G} 3$.

Besides, the sequence S3 was partly done in collaboration with the larger institutional process of the SAR revision, which gathered 200 stakeholders from regional institutions and of the civil society. The SAR revision associated regional elected representatives together with representatives of the agricultural industries (cane and cattle), urban planners and conservation institutions (National Park, National Forest Office, Regional Environmental Affairs, etc.). The SAR revision was organised in three stages. In the 'diagnostic' stage, stakeholders identified the main challenges for the future of Réunion Island. In the 'scenario development' stage, they extracted and ranked a subset of key challenges and built four contrasted land-use planning scenarios by ranking those challenges (Table 2). Lastly, based on the debate emerging from the simulation of those scenarios in collaboration with S3, they identified the main stakes and means of action to identify the most appropriate future land-use for the Island.

\section{$\underline{\text { Table } 2}$}

We assessed the impacts on biodiversity of land-use scenarios developed in S3. That simulation only involved researchers. We intended it to be participatory but the group in charge of the SAR revision didn't want to discuss conservation issues collectively, preferring to deal directly with representatives of the strongest conservation stakeholders: the Regional Environmental Affairs (hereafter DIREN).

\section{Sequence 1: Participatory mapping of land-use and biodiversity}

\subsection{Objectives and participants}

In this first sequence, the objective was to develop a map of ecological habitat units, compatible with conventional land-use maps of urban and agriculture areas. Such maps facilitate the integration of conservation issues into the land-use debate and act as good surrogates for biodiversity as a whole (Lombard et al., 2003). Additional maps on conservation-related issues (species distribution for instance) were also collected during the workshop.

\subsection{Material and methods}

We integrated expert judgements with field survey, remote sensing data and GIS analysis to develop a combined land-use and biodiversity map during a one-day workshop. 
important to conserve ecological linkages between the oceanic and the terrestrial domain.

The discussions among participants focused mainly on the definition of habitat categories compatible with operational land-use planning. For instance, the categorisation of agricultural activities was heavily discussed, some stakeholders willing to impose a very detailed categorisation incompatible with the objectives of the project. The selection of data sources was discussed as well. Each sector wanted to impose its own GIS layer, which resulted in major overlaps among layers. For instance, in the lowlands, urban areas overlapped with large agricultural areas mapped by stakeholders from the agricultural sector. To solve such overlay conflicts (i.e. sites having different land-use in at least two layers), participants agreed on a specific priority order with urban areas superimposing to all other categories. The final habitat map is thus a negotiated combination of all GIS layers provided by the different sectors.

It soon appeared obvious that through their definition of the land-use system, each sector was trying to defend its own mental categorisation of the landscape. The land-use categories representing ecological habitats, proposed by the conservationists, were not well understood by the other participants who found them too complex and detailed. Divergences among participants also emerged when attributing a "transformed but restorable" status to areas suitable for agriculture in the uplands. The attribution of a "pristine" status to areas located outside the margin of protected areas also involved heavy debates between conservationists and participants from the agricultural sector. Agricultural stakeholder seemed to fear that conservationists implement conservation measures that prevent them from cultivating their land in the future.

\section{Sequence 2: Participatory conservation planning}

\subsection{Objectives and participants}

In this second participatory modelling sequence we followed a systematic conservation planning approach (Cowling et al., 2003) to identify an optimal spatial network of priority areas for conservation. Each biodiversity feature was assigned quantitative conservation targets. An average surface target of $30 \%$ of their initial area (e.g., before human colonization) was assigned to each pristine habitat category. The distribution of habitats before human colonization was developed by Strasberg et al. (2005) using expert knowledge and GIS data on altitude and rainfall.

\subsection{Material and methods}

We used the conservation planning software MARXAN (Ball and Possingham, 2000), and its interface CLUZ (Smith, 2004) in Arcview 3.2 (ESRI, Redlands, California) to develop the conservation plan. MARXAN allows the users i) to assess the contribution of a reserve system to achieve conservation targets and ii) to select a near-optimal network of complementary reserves that achieve conservation targets (Sarkar and Margules 2002). This complementary reserve network contributes to the achievement of conservation targets. Consequently, it should be conserved in the future, in addition to the current reserve network. 
MARXAN software is designed with the use of stochastic optimization routines (simulated annealing, Kirkpatrick, 1983). Following an iterative selection process, the algorithm attempts identify a near-optimal reserve system called solution, by minimising its total cost (Possingham et al., 2000). Planning units frequently integrated within solutions are the most irreplaceable (MARXAN sensu).

The costs and the number of runs have been calibrated heuristically with conservation scientists and adjusted along the simulation sequence (see Ardron et al. (2008) for more details about MARXAN parameters settings). In our case, the costs used for the optimization were non-monetary values estimated on the basis of their relative importance by scientists from $\mathrm{G} 1$. As explained on Figure 3, three categories of cost were estimated:

- First, the "fine" to be paid if a conservation target is not achieved. We attributed a prohibitive value of 10 million per biodiversity feature to this parameter. Thus we ensured that each solution adequately represented all features.

- Second, the cost of each planning unit per $\mathrm{km}^{2}$ per year. To calculate this parameter, we developed a synthetic index of conservation costs (SICC). The SICC is calculated by summing the following variables detailed in Table 3: implementation cost, invasive plants control cost, restoration cost and conversion pressure cost. The resulting SICC in Réunion Island varied from 3 (attractive) in the uplands, to 37 (repulsive) in the lowlands.

\section{$\underline{\text { Table } 3}$}

- Third, the boundary length cost which is the cost associated with the management of reserve boundaries per km per year. Increasing this cost promotes the compactness of the reserve network identified.

The model validation was done by $\mathrm{G} 1$ members, by comparing the final map of conservation priorities to their own mental representations of conservation priorities in the landscape.

For the purpose of the analysis, the planning domain was divided into square cells of 4 ha, similar to those used in the MAS simulation model (see Section 6). The 4 ha resolution was chosen as the best compromise between data processing constraints, spatial resolution of input data and management requirements.

\section{Figure 3}

\subsection{Outputs}

The main output of the modelling sequence was a map of priority areas for conservation actions. This map shows the distribution of highly irreplaceable conservation sites and corridors (Figure 7). The priority areas encompassed 1508 $\mathrm{km}^{2}$ of land (Figures $7 \mathrm{~b}$ and 7c) of which approximately $500 \mathrm{~km}^{2}$ is not currently protected and should be allocated to some form of conservation management to ensure the persistence of the documented biodiversity of Réunion Island. 
The development of the modelling sequence involved vigorous debate among participants. Some participants argued that the modelling process was a waste of time as they already knew where the priority areas for conservation were. For them, the problem was not to know where to intervene but rather how to negotiate and implement interventions. The concept of conservation targets also raised polemics among the group, as participants argued that biodiversity conservation couldn't be resumed to quantitative objectives. Those participants were also reluctant to use a cost-based approach to conservation planning. Given this lack of global buy-in from the participants, we discarded the idea of involving land-use stakeholders in the conservation planning process as initially stated. Despite disagreements about the method, all participants agreed about the output map of priority areas.

Finally, the map of priority areas for conservation was presented within a wide array of public arenas, including regional administrations (Regional Scientific Council, Departmental Office of Sensible Natural Sites) and state institutions (National Forest Office). Feedbacks from those institutions are discussed in Section 7.

\section{Sequence 3: Participatory land-use planning using a scenario simulation model}

\subsection{Objectives and participants}

The main purpose of this third modelling sequence was to illustrate the need for compromises among land-use sectors with a land-use simulation tool that would be accepted by representative of each sector, rather than to find new results in terms of land-use dynamics. To do so, we choose to involved stakeholders from the beginning of the modelling sequence.

We built a multi-agents model (MAS) with stakeholders and researchers, called 'DS'1 to simulate prospective land-use scenarios (Botta et al., 2009; Daré et al., 2008). To this purpose, we adopted a ComMod approach, organised into iterative cycles. During the model development phase, those cycles involved the progressive definition of hypothesis on the structure and dynamics as well as of indicators. During the simulation phase, planning hypotheses identified by the participants in the diagnostic stage of the SAR revision process were progressively translated within the G3 group into simulation scenarios. The final model outputs were then evaluated by all the participants of the SAR revision process.

\subsection{Material and methods}

The MAS modelling process focused on the interactions between three major classes of land-use: natural, agricultural, and urban. Considering that urban sprawl is driven by demography, the urban expansion is driven by the population dynamics (growth) and its distribution on the territory. The final land-use simulation model is therefore composed of two coupled dynamics: a population dynamic (evolution,

\footnotetext{
${ }^{1}$ DS acronym stands for Domino (the name of the project) and Smat (the name of a first multi-agent model prototype we developed for the population dynamic)
} 
density and distribution of the population) and a land-use dynamic (land-use changes).

The first stage in the elaboration of the MAS simulation model was to determine and specify its social and spatial entities. The second stage of the MAS modelling was then to define their organisation and the dynamics of their interactions. This entailed the sequencing and ordering of the interactions among social agents and spatial entities. To this purpose, the group of modelling participants was split into three sub-groups representing the agriculture, urbanisation and conservation sectors. Each group modelled a specific set of dynamic interactions related to its sector and a first prototype of MAS was then assembled and discussed. The third stage involved the co-construction of land-use scenarios and their translation in the model (Table 2).

We implemented the complete DS model (David et al., 2007) on the multi-agent simulation platform GEAMAS-NG (Payet et al., 2006) developed at the University of Réunion Island. We had to detail two kinds of entities: the agents representing social entities and the elements of their environment representing spatial entities. All the DS entities that we describe in the following paragraphs are represented on the UML diagram on Figure 4.

\section{Figure 4}

The environment is composed of elementary spatial square units of land that we call cells. For this application we used 4 ha cells $(63245$ cells to cover the whole island), but the model allows the user to perform simulations (for the whole island or in sub-regions of the island) with other cells size.

The population dynamic is obtained through interactions between three kinds of agents: region, micro-region, and land parcels. For this application, there was only one region agent (the Island) and four micro-regions agents (Northern, Southern, Eastern and Western micro-regions of the Island). The land parcels agents are as many as the cells of the environment. Note that the land parcels and the cells are different entities: the first ones are agents, with an internal behaviour, whereas the second ones are simple objects of the environment that can be manipulated by the agents of the system. Those agents run on demographic parameter values (birth, death, and immigration rates) provided by the French National Institute of Statistics and Economic Studies (INSEE). At the beginning of the simulation the land parcels agents are initialized with an initial population (802 000 in 2006) and with local birth rate $(1.8 \%$ in 2006$)$ and death rates $(0.5 \%$ in 2006$)$. During the simulation each land parcel agent calculates a new population that is communicated to its belonged agents micro-region and region. The population coming from each land parcel is then modified by migration and densification processes at the micro-regional and regional levels. This enables the region agent to calculate the new population of the whole island and to spread up this population to the land parcels according to the sprawling and densification parameters defined by users in the simulation scenario.

Land-use dynamic is supervised at regional level by three macro-agents that interact with the cells of the environment. They represent respectively the urban, the agricultural and the natural sector. Those agents act as global surrogates for the real process of land-use change, which results from the decisions of several individual 
land owners. Although this modelling choice seems to oversimplify the system, it was accepted by the G2 participants as a solution to overcome the disagreement among them on the way to go more into details, and it avoided a tricky calibration process.

At the beginning of a simulation, each cell is initialized with a unique land-use informed by the land-use map developed in the modelling sequence S1: natural, agricultural or urban. Each cell is also attributed a suitability score for each activity (conservation, urbanisation and agriculture). These suitability scores were scaled as follows: null, low, medium and high. And they were assigned to the cells by using a configuration method that consisted in initializing the cells with information coming from several semantic colour maps of the island (Payet et al., 2007); each colour corresponding to one of the four possible suitability scores. Suitability for conservation was set according to the transformation status of habitats, ranking from irreversibly transformed (suitability = null) to pristine (high) (see Section 5 and Figure 2a). The suitability map for urbanisation was developed by the urban planner of the team in charge of the SAR revision. Suitability for agriculture was defined by agricultural stakeholders of $\mathrm{G} 2$ based on a comprehensive GIS analysis of agronomic factors (soil, slope, accessibility, etc.). The last two suitability maps were also used to calculate the "conversion pressure cost" layer in MARXAN (Table 3).

Each year, during simulation, the three macro-agents reassess and convert the state of the cells to the benefit of their activity sector. Each macro-agent tries to change land-use in some of the cells that it considers to be the most suitable for urbanization (urban macro-agent), agriculture (agriculture macro-agent) or conservation (conservation macro-agent). Such changes are operated in order to reach sectoral objectives fixed by the simulation parameters and the evolution of the population dynamic. If more cells than required to satisfy one macro-agent have a same best suitability score, the choice of the cells to be changed by the concerned macro-agent is randomized.

Land-use restrictions are implemented to constrain land-use changes. Globally, we considered that urban is an irreversible state and a cultivated cell cannot become again a natural cell, i.e. ecological restoration isn't possible. A cell flagged with a "restriction" attribute is a cell where conversion is no longer possible. The conservation macro-agent implements such flags in cells suitable for conservation. Other macro-agents may not respect those flags depending on the simulation settings, i.e. they can ignore protected areas proposed by the conservation macroagent. All those settings have been discussed with the participants from G3.

Through land-use changes, the agricultural and conservation sector macroagents try to achieve a surface target. To achieve this target, each sector is allocated a yearly conversion quota. For instance, in the Trend-oriented scenario, the agricultural sector macro-agent targeted a stable surface and was allowed to convert a quota of 1000 ha of land to agriculture each year during the 25 years of the simulated scenario (2005-2030). The conversion quota was set for each sector and for each scenario with the participants based on the spatial objective of each sector. Those objectives had been derived from the SAR scenarios and reflected distinct development options for the Island.

The target for the urban sector macro-agent is expressed as a human density threshold per cell. Once this threshold is reached, the urban macro-agent tries to convert non-urban cells to urban cells. This constitutes the main coupling point between the land-use dynamic and the population dynamic: the human density 
threshold is reached by the population dynamic agents and then acts as a stimulus leading to the urbanisation of non-urban cells by the urban macro-agent of the landuse dynamic. More details about the population dynamics and its link with the urbanisation process at various levels can be found in Botta et al. (2009).

The set of land-use conversion rules and the priority order among social agents for allocating cells was defined by the user at the beginning of the simulation. For the simulations presented in this article, the priority order among sectors was: Urban > Agricultural > Conservation. Following the opinions of G2 members, this priority order is conform to real spatial planning processes in Réunion Island.

At the end of each simulation, the model provides outputs and indicators: i) log files containing information on the simulation process (for instance, achieved target for the agricultural sectors in ha), ii) graphics showing compared evolutions of the three land-use categories (in ha) and iii) maps showing spatial data such as the « new » land-use map of the island (exportable in GIS grid format).

An interface allows the user to build a scenario of simulation (for instance, a rapid urban sprawl combined with a complete conservation of pristine habitats), by initializing a specific set of parameters (see Figure 5). In the sequence $S 3$, the scenarios were inherited from the participatory process developed among the large group of SAR revision participants. G3 members adjusted the model prototype to enable it to translate these scenarios into simulations in DS. DS was then used to assess the impacts of the various scenarios on land-use and biodiversity up until 2030, with a yearly temporal resolution (Table 4).

\section{Figure 5}

\section{$\underline{\text { Table } 4}$}

The four main scenarios were namely the Trend scenario, the Urbanisationoriented scenario, the Nature-friendly scenario and the Economy-oriented scenario. The first scenario depicted what would happen if there was no change in the current territorial dynamics. The three other ones referred to the main challenges for the Island: rationalising urban sprawl by housing one million of inhabitants, conserving resources, developing its economy. Each of these scenarios explored what would happen if one of these challenges was prevailing on the others. They are resumed in Table 2, for more detail see Conseil Régional de la Réunion (2009).

All scenarios had to be simplified to be translated into DS. For example, social or transportation aspects were ignored as they were impossible to represent in DS. The stakeholders validated the outputs of the model based on their plausibility, and more so by looking at their differences when compared to the outputs of the trend scenario.

\subsection{Outputs}

As expected, all four scenarios simulated that the agricultural sector is hugely 593 impacted by urbanisation. By domino effect, this urbanisation in the lowlands affects 
pristine habitat in the uplands as the agricultural sector, to maintain its surface, convert natural landscapes on its upper margins. DS model reproduces such landuse competition mechanism and its indirect impacts on biodiversity in Réunion Island.

The best SAR scenario for biodiversity was as expected the Nature-friendly one (Figure 6a), whereas the Economy-oriented scenario (Figure 6b) was the worst. The Economy-oriented scenario involved high urban densification and a surface target for the agricultural sector of $25 \%$ more of surface in the next 15 years (Table 4 ). This scenario would lead to the conversion of $3 \%$ of the current pristine habitats and would impact more than $15 \%$ of the recorded distribution of indigenous species.

\section{Figure 6}

In the Urbanisation-oriented scenario, the loss of agricultural land due to urbanisation was compensated by the cultivation of large natural areas in the uplands. Although it did not implicate a high rate of conversion of pristine habitats, the Trend scenario was associated with a major socio-economic crisis due to insufficient housing capacities and weak governance of land-use development (uncontrolled urban sprawl) (Table 4).

As the modelling process moved toward the regional land-use planning arena (SAR), the composition of the G2 participatory group broadened, with new participants such as members of extension and support services for urban development joining the team. At the same time, conservationists, particularly those from G1 group, were excluded from the simulation process. This resulted in the conservation sector and certain important agricultural role players being absent from the G3 group. To build the final regional plan, the SAR team organised later some bilateral groups with specific theme (agriculture; natural resources, etc).

To motivate their decision to exclude conservationists, the group in charge of the SAR revision argued that the conservation stake would not be discussed collectively but rather between themselves and the representative of the strongest conservation representative: the DIREN. Finally, the conservation planning products resulting from the two first sequences were not used for the SAR revision process. The decision of not integrating the outputs of the conservation plan in the SAR was perceived as a failure by the conservationists involved, and raised question about the "return on investment" of the conservation planning approach implemented in Sequence 2.

Independently from $\mathrm{G} 2$ and $\mathrm{G} 3$, researchers from the $\mathrm{G} 1$ team then decided to simulate alternatives to the SAR Trend scenario in order to assess the impacts of implementing the additional $500 \mathrm{~km}^{2}$ reserves network (i.e. irreplaceable sites and conservation corridors) identified in Sequence 2. Results show that implementing those reserves would result in a 2100 ha loss for the agricultural sector $(7 \%$ of the current agriculture area). However, the simulation also revealed that, in addition to the land conversion restriction imposed by the new reserves in the uplands, concomitant urbanisation in the lowlands would explain approximately $50 \%$ of this loss (Figure 7). Indeed, the exponential shape of the unachieved demand for agricultural land on Figure 7 is due to the concomitant conversion of agricultural land by urbanisation in the lowlands. 
The results of the sequence S2 that showed the necessity of expanding protected areas in the lowlands and the results of S3 showing the impacts of the SAR scenarios on biodiversity were presented to the staff of the National Park and National Forest Office. Recently, the scientific unit of the National Park contacted G1 to prioritize sites for conservation actions within the boundaries of the National Park.

\section{Discussion: Can participatory modelling promote integrating conservation with land-use planning?}

\subsection{Impacts of the modelling sequences on the integration of conservation with land-use planning}

The impacts of a participatory modelling process remain difficult to evaluate because they are the result of complex interactions and can't therefore be analysed independently, using single indicators of success (Ludwig, 2001). Here, we discuss them based on the observations made by the participatory modelling investigators during and 12 months after the process.

Jiggins and Röling (2002), distinguish three categories of participatory modelling processes depending on their expected impacts : i) generating social robust knowledge for effective and efficient policy-making, ii) enhancing social learning and capacity building for practical problem-solving and, iii) empowering and advocating for socio-political transformation. Although each of our modelling sequence combines several of these objectives, we can identify a dominant one. The modelling sequences $\mathrm{S} 1$ and $\mathrm{S} 2$ relate mostly to the first category where scientific knowledge is assumed to lead toward better decision making if it can be socially appropriated by the stakeholders. These sequences partly answer the two first objectives of this study: the identification of priority areas for conservation and the provision of guidelines for implementing conservation actions outside existing reserves while dealing with increasing pressuring factors in the lowlands. The type of knowledge represented in the models is mostly scientific. The last sequence S3 rather belongs to the second category, where the investigator of the modelling process is a facilitator to social-ecological learning, opinion sharing and elicitation toward better management decision. The participants to the sequence S3 have mostly learned about each other and less about their own practices.

Learning and awareness-raising were important outcomes of the modelling sequences (Armitage at al., 2008). They led to the development of new knowledge about the territory and its biodiversity in Réunion Island. The participants developed a better understanding of the system, similar to what Bolte et al. (2007) observed in their experiment. For instance, the conservation planning sequence demonstrated the risks associated with the lack of biodiversity protection in the lowlands. DS model reproduced their understanding of the impacts of each sector (agriculture, urbanisation and conservation) on the landscape and on biodiversity: It showed the cascading effects of urbanisation: the conversion of agricultural land and finally the conversion of pristine habitats. We also assessed the impact of implementing additional protected areas on the agricultural sector (Figure 7). 
By measuring trade-off between the conservation and the agricultural activities in the landscape, we were able to extend our answer to the 4th objective of our study: the exploration of alternative scenarios for land-use and conservation planning. Trade-offs shown in Figure 6 are reasonably plausible. Nevertheless, the impacts of the economy-oriented scenarios on species seem overestimated as some individuals might persist within small vegetation patches in cultivated cells. However, on the long term such rates of species distribution erosion are likely to occur. 30 out of 45 vertebrate species went extinct since human occupation of the island (Cheke, 1987).

As a positive externality of the participative modelling sequences, the participants learned technically about the co-construction of GIS layers on biodiversity and land-use, and more generally about the use of a spatial simulation model. To develop the MAS model or to run MARXAN, the participants stated their objectives and preferences for their activity sector in quantitative terms, for instance by setting spatial targets for agriculture expansion. This process is called "elicitation" by Ferber and Guerin, 2003. They had to share those statements with other participants, thus clarifying and structuring the debate on land-use and conservation planning issues.

The participants learned about the other activity sectors mostly during the third modelling sequence, by sharing knowledge with the other participants. They were more able to better understand the "mechanics" of the other sectors (also called "decentration" process by Ferber and Guerin, 2003). For instance, the participants better understood the pressures exerted by urban sprawl on the agricultural sector. In return, the complexity of urban planning was made evident to all participants.

The last objective: "to 'accompany' the conservation sector to negotiate land-use planning and decision-making, more particularly in relation to the new regional landuse plan and the management plan of the National Park" was the less achieved of our objectives, as all the representatives of the conservation sector were evinced from the S3 sequence. Although the results of the three sequences were presented to other conservation stakeholders afterward, they didn't seem to use this knowledge within the SAR revision process. Nevertheless, the National Park is interested in using the conservation plan developed in S2 for prioritizing conservation sites within its boundaries.

Globally, the debates occurring during the three modelling sequences highlighted that the interactions occurring among the activity sectors involved in spatial planning cannot be resumed to spatial processes. The whole study also made evident that land-use policies and conservation are intrinsically interlinked. Those results question the utility of conservation planning when the conservation plan is undertaken independently from land-use planning.

\subsection{The value of the participatory modelling process}

The value of the participatory modelling process always depends on the willingness of participants to really engage in it. For instance, the national forest office (ONF) representative refused to participate. This would have weakened its position for negotiating the future institutional mandate of the ONF in a context of institutional competition with the National Park. Although the participatory modelling sequences intended to reduce information asymmetry among stakeholders from a range of activity sectors we must acknowledge that part of the information wasn't 
elicited and remains cryptic. Most institutional participants never revealed their strategy, indicating that tensions for power continue to cloud participatory experiments in accordance with stakeholders' respective agendas (Wallace, 2003).

The participatory modelling sequences aimed to link land-use planning with biodiversity conservation and to promote stakeholders' participation, while accompanying regional decision making. The knowledge of researchers and stakeholders were integrated in the early stages when building land-use GIS layers (S1). Globally, this strategy improved the connectivity between research and stakeholders for planning land-use (Turton et al., 2007). Although the sequences S1 and S3 gathered success from a participatory point of view, the participatory planning sequence $\mathrm{S} 2$ progressed with difficulties.

The modelling approach implemented in S2 aimed to 'mainstream' (Smit and Wandel, 2006) biodiversity considerations within land-use decision making and to maintain a continuum of actions linking conservation science to implementation (Venter and Breen, 1998, Cowling, 2005). Although the conservation planning products (map of conservation priorities) were successfully developed, those objectives were far from being achieved. We analyse three possible explanations of this failure in the following paragraphs.

The modelling tool we used in S2. MARXAN is a rigid and complex tool. In addition, this tool embeds strong hypothesis about land-use management and conservation, such as, for instance, the attribution of a value to biodiversity features. The participants globally disagreed with this approach and thus rejected the tool. Paradoxically, they agreed with the map of conservation priorities produced using MARXAN.

The implementation of new conservation measure is not socially acceptable as a major proportion of the island territory $(43 \%)$ is already protected within reserves (mainly the National Park). Concomitantly, basic societal needs such as housing and transport are not satisfied. This paradox creates tensions within the society and among stakeholders. The global perception is that conservationists already achieved their objectives through the creation of the National Park. Consequently, other stakeholders prevent the integration of conservationists in the land-use debate.

State institutions, including the DIREN and the National Forest Office have operated as exclusive representatives of the conservation sector within the land-use debate. In reality, the conservation sector is plural and heterogeneous, also composed of non-governmental organisations (National Botanical Garden, SREPEN, Vie Océane and Association Nature et Patrimoine among others) and individuals. In the sensitive context of the implementation of the National Park those institutions needed to control the conservation debate and this could explain why noninstitutional conservationists (e.g. scientists for instance) were ousted from the SAR revision. This will probably change when the newly declared National Park will be firmly implemented, as its governance associates members from the civil society.

\subsection{The researcher's posture in the participatory modelling process}

Analysing and questioning researcher's posture in a context of action research is central to understand their relationship to the participatory process and to the others participants. Here, we distinguish the researcher-organisers who led the participatory modelling process from the researcher-participants involved in it. 
In S1 researcher-participants were initially perceived as neutral data providers by stakeholders external to the process. Nevertheless, some researchers left this methodological stance to justify the attribution of a conservation value to agricultural landscapes. This shift of posture created tension among researchers from $\mathrm{G} 1$ and $\mathrm{G} 2$ and stakeholders from the agricultural sector from $\mathrm{G} 2$.

In S2 the researchers-organisers soon embraced a conservationist posture stating that the implementation of complementary reserves in the lowlands was needed. This statement was based on a so-called objective knowledge of the increasing pressures on biodiversity. In fact, most conservation planning applications are based on such pre-determined statement and view the participatory process as a way to impose those statements to stakeholders. This partial stance is another possible explanation of the exclusion of biodiversity researchers from the SAR revision: in S3, "conservation-friendly" researchers would have aggravated tensions among stakeholders involved in the land-use debate.

The researchers-organisers in the $\mathrm{S} 3$ adopted the ComMod posture described in Bousquet et al. (1999). As neutrality is quite impossible in a participatory process, they tried to be as clearer as possible about their hypotheses; their stakes and their objectives. To this purpose, they involved stakeholders in the first steps of the building of the social-ecological model. The complexity of natural and social dynamics was shared with all participants of G2. The simplifications were recognized by all participants as necessary to achieve the common objectives: to create a model really useful for the SAR revision. The compromises were also made altogether. This open modelling process was time consuming but helpful to build a common vision of the structure and dynamics of the system represented in the model and its limits (Daré et al, 2008; Daré et al, 2006). This posture facilitated information and data transmission from researchers to stakeholders and vice versa. This posture reinforced the trust between $\mathrm{G} 2$ members, which was also helpful when the model created with $\mathrm{G} 2$ was modified with $\mathrm{G} 3$ members.

\section{General research implications and perspectives}

For many years, the issue of interactions between nature and society has been investigated by researchers from various study fields with their particular background, focus and methods. Thus, conservation planning has long been guided by the positivist paradigm in which humanity is viewed as an external threat to the internal equilibrium of a pre-extant nature. Opposed to this vision, we view the human-nature system as a whole evolving, heterogeneous and complex system of mutual interactions between society and nature (Holling, 1987, Gunderson and Holling, 2002, Folke et al., 2005).

More recently, nature and social science met in the holistic paradigm of constructivism (Piaget, 1967, see also Bourdieu, 1987). Constructivism relates to the idea of post-modernism, post-normal science (Funtowicz and Ravetz, 1991) and soft systems (Checkland and Scholes, 1990). Constructivism states that there is not an objective reality but that the reality is constructed by the individual based on its knowledge. In our study, we adopted this conceptual scheme to develop the participatory modelling sequences. This approach that recognises the existence and legitimacy of a diversity of points of view about the system management (here, landuse and biodiversity) need to be investigated by conservation planners (Bolte et al., 
2007). Although many conservationists embrace an ethical-moral approach, claiming that the right of nature to exist should be considered regardless of its contribution to society (Beatley, 1989), we considered them as legitimate stakeholders among others.

More practically, our study points out the limitations of the systematic conservation planning framework (Cowling at al., 2003, Knight et al., 2006). This framework is a reference for conservation planning applications worldwide. It involves a social and a biological assessment followed by a planning step and a stakeholders' involvement. The basic assumption is that the stakeholders will follow the conclusions derived from the planning. In practice the stakeholders' involvement rarely happens and the planning step is done by a narrow group of conservation experts who make strong assumptions about the territory. The focus is often made on strict ecological aspects and the social assessment is generally designed similarly to a biological assessment focusing mainly on mapping human activities in the landscape. Our study shows that conservation planning shouldn't be limited to a scientific modelling exercise disconnected from broader societal considerations. Socalled conservation planners should rather engage within existing decision-making arenas and institutions to integrate biodiversity conservation into land-use planning.

Conservation planning applications are generally implemented using plug-andplay conservation software. Such normative tools (and affiliated conceptual frameworks) channel interactions with stakeholders and restrict them. For instance, in MARXAN (Ball and Possingham, 2000) all aspects of the conservation plan are reduced to costs. Such implicit assumptions often fail to reflect the non-monetary values of stakeholders. Consequently, stakeholders often end up very frustrated as most of their complex and specific issues do not fit in this framework. This is, in fact, inefficient as the conservation planning process is then rejected by stakeholders and not implemented. Participatory modelling is a way to avoid this failure by involving stakeholders earlier in the "modelling for planning" process so that they co-construct it.

More effort should be deployed to connect conservation planning processes with public spatial planning processes. Our study shows that this complexity can only be addressed through better integration of biodiversity conservation issues into mainstream land-use planning (Cowling, 2005). To this purpose, a combination of a systematic conservation planning approach with a participatory modelling approach is a research direction to investigate further. Future research should focus on a closer integration of spatial modelling tools (optimization and simulation), biodiversity mapping, scenario building and stakeholder integration.

Finally, we do not believe that models are the Holy Grail of spatial planning. They are, however, useful to support negotiations processes among stakeholders. Conservation planning is a component of land-use planning, not the converse. In this framework, a companion modelling approach would promote the integration of conservation into the land-use planning debate, thus contributing to develop and to maintain a research-implementation continuum that will promote integrated biodiversity conservation.

\section{Acknowledgment}


We thank all the participants to the modelling sequences. These analyses were part of two projects: APIC-BIO and DOMINO.APIC-BIO was funded by the CIRAD, the Regional Council of Réunion and the European Union (INTERREG 3B, FEDER). DOMINO was funded by the CIRAD, the Régional Council of Réunion, the European Union, and the ANR program "Agricultures et Développement Durable" (projet ComMod « La modélisation d'accompagnement : une pratique de recherche en appui au développement durable, ANR-05-PADD-007 »). APIC-BIO involved the following institutions: Cirad, University of Réunion Island, Regional Council of Réunion, South African National Biodiversity Institute, Mission Parc National de la Réunion. DOMINO involved the following institutions: CIRAD, Université de la Réunion, Chambre d'Agriculture de la Réunion, Comité de pilotage de la canne, Association pour la promotion en milieu rural, Conseil régional de la Réunion.

The following persons also contributed to the project: M. Lombard, D. Strasberg, A. Thomassin, B. Ayache, S. Manglou and N. Clavaud. We are grateful to three reviewers for their constructive comments on previous versions of this article.

\section{References}

Acevedo, M.F., Callicott, J.B., Monticino, M., Lyons, D., Palomino, J., Rosales, J., Delgado, L., Ablan, M., Davila, J., Tonella, G., Ramirez, H., Vilanova, E., 2007. Models of natural and human dynamics in forest landscapes: Cross-site and crosscultural synthesis. Geoforum 39 (2) 846-866.

Ardron, J.A., Possingham, H.P., Klein, C.J. (eds), 2008. MARXAN good practices handbook. External review version; 17 May, 2008. Pacific Marine Analysis and Research Association, Vancouver, BC, Canada [on line] www.pacmara.org

Arendt, R., 2003. Linked landscapes: Creating greenway corridors through conservation subdivision design strategies in the north eastern and central United States. Landscape and Urban Planning 68 (2-3) 241-269.

Armitage, D., Marschke, M., Plummer, R., 2008. Adaptive co-management and the paradox of learning. Global environmental change18 86-98.

Ball, I.R., Possingham, H.P., 2000. MARXAN (V1.8.2): Marine reserve design using spatially explicit annealing, a manual.

Baret, S., M. Rouget, Richardson, D.M., Lavergne, C., Egoh, D., Dupont, J., Strasberg, D., 2006. Current distribution and potential extant of the most invasive alien species on La Réunion (Indian Ocean, Mascarene Islands). Austral Ecology 31: 747-758.

Barreteau, O., Antona, M., D'Aquino, P., Aubert, S., Boissau, S., Bousquet, F., Daré, W., Etienne, M., Page, C.L., Mathevet, R., Trébuil, G., Weber, J., 2003. Our companion modelling approach (La modélisation comme outil d'accompagnement). Journal of Artificial Societies and Social Simulation 6 (2) 1 [on line] http://jasss.soc.surrey.ac.uk/6/2/1.html

Beatley, T., 1989. Environmental ethics and planning theory. Journal of Planning 915 Literature 4 (1) 1-32. 
Bolte J.-P., Hulse D. W., Gregory S. V., Smith C., 2007. Modeling biocomplexity actors, landscapes and alternative futures. Environmental Modelling \& Software 22

Botta A., Dare W., Antona M., et Leclerc G., 2009. Integration of multi-scale stakes in governance by applying companion modelling to land-use foresight. In Anderssen, R.S., R.D. Braddock and L.T.H. Newham (eds) 18th World IMACS Congress and MODSIM09 International Congress on Modelling and Simulation. Modelling and Simulation Society of Australia and New Zealand and International Association for Mathematics and Computers in Simulation, July 2009, pp. 2377-2383. ISBN: 978-09758400-7-8. http://www.mssanz.org.au/modsim09/F1/Botta.pdf.

Bourdieu, P., 1987. Choses dites. Espace social et pouvoir symbolique. Editions de Minuit, Paris, 147-166.

Bousquet, F., Barreteau, O., Le Page, C., Mullon, C. and Weber, J., 1999. An environmental modelling approach. The use of multi-agents simulations. In: $F$. Blasco and A. Weill (Editor), Advances in Environmental and Ecological Modelling. Elsevier, Paris, 113-122.

Bousquet, F., Le Page, C., 2004. Multi-agent simulations and ecosystem management: a review. Ecological Modelling 176 313-332.

Brown, K., 2003. Tree challenges for a real people-centred conservation. Global Ecology \& Biogeography 12 89-92.

Cadet, T., 1980. La végétation de l'île de La Réunion, étude phytoécologique et phytosociologique. PhD thesis, Université d'Aix Marseille.Castella, J.-C., Trung, T. N, Boissau, S., 2005. Participatory simulation of land-use changes in the Northern mountains of Vietnam: the combined use of an Agent-Based Model, a Role-Playing Game, and a Geographic Information System." Ecology and Society 10 (1) 27. [on line] http://www.ecologyandsociety.org/vol10/iss1/art27/

Checkland, P., Scholes, I., 1990. Soft System Methodology in Action. John Wiley \& Sons, Chicester.

Cheke, A. S., 1987. An ecological history of the Mascarene Islands, with particular reference to extinctions and introduction of land vertebrates. 5-89. In: Diamond, A. W., Studies of the Mascarene Islands Birds. Cambridge, Cambridge University Press.

Conseil Régional de la Réunion - Mission d'assistance à la révision du SAR, Groupement SETEC organisation et Safège, 2007. Révision du S.A.R. de la Réunion, scenarii d'aménagement et de développement de la Réunion en 2030, rapport provisoire février 2007.

Conseil Régional de la Réunion, 2009. Schéma d’Aménagement Régional de La Réunion, rapport volume 2, $139 \mathrm{p}$.

Cowling, R. M., 2005. Maintaining the research-implementation continuum in conservation. Society for conservation biology newsletter 12(4) [on line] www.conbio.org/Publications/Newsletter/Archives/2005-9a-November/v12n4.rtf 
957 Cowling, R.M., Pressey, R.L., Rouget, M., Lombard, A.T., 2003. A conservation plan 958 for a global biodiversity hotspot--the Cape Floristic Region, South Africa. Biological 959 Conservation $112(1-2)$ 191-216.

960 David, D., Payet, D., Botta, A., Lajoie, G., Manglou, S., Courdier, R, 2007 Un couplage de dynamiques comportementales : Le modèle DS pour l'aménagement du territoire. Actes des Journées Francophones Systèmes Multi-Agents (JFSMA'07), Carcassonne, France, oct. 17-19, Cepadue, 129-138.

Daré W., Aubert S., Bah A., Gaye I.D., Fourage C., Lajoie G., Leclerc G.. 2008. Difficultés de la participation en recherche-action : retour d'expériences de modélisation d'accompagnement en appui à l'aménagement du territoire au Sénégal et à la Réunion. VertigO, 8 (2). http://vertigo.revues.org/index5012.html

Daré W., Fourage C., Gaye I.D.. 2006. Methodological issues arisen from the involvement of sociologists in the Domino project, a companion modelling approach: interests and limits, The quality of social existence in a globalising world : XVI World Congress of Sociology, 23-29 July, 2006, Durban, South Africa.

Département de la Réunion 2006. Cahiers de l'agriculture [online] http://www.cg974.fr/images/pdf/agriculture/Les\%20Cahiers\%20de\%20l\%27agricultur e.pdf

Driver, A., Cowling, R., Maze, K., 2003. Planning for living landscapes: perspectives and lessons from South Africa. Cape Town Botanical Society of South Africa.

Etienne, M., Le Page, C. and Cohen M., 2003. A Step-by-step approach to building land management scenarios based on multiple viewpoints on multi-agent system simulations , Journal of Artificial Societies and Social Simulation 6 (2) 2 [on line] http://jasss.soc.surrey.ac.uk/6/2/2.html

Ferber, J., Guerin, V., 2003. Le statut épistémologique de la simulation. Les actes des 10emes journées de Rochebrune. 85-98.

Ferrand, N., 1997. Modèles Multi-Agents pour l'aide à la décision et la négociation en aménagement du territoire. PhD thesis, Université J. Fourier, Grenoble.

Folke, C., Hahn, T. Olsson, P., Norberg J., 2005. Adaptive governance of socialecological systems. Annual Review of Environment and Resources 30 441-473.

Funtowicz, S., Ravetz, J.R., 1991. A new scientific methodology for global environmental issues. 137-152. In: Costanza, R. (Eds.), Ecological Economics: The Science and Management of Sustainability, Columbia University Press, New York.

Gigord, L., Picot, F., Shykoff, J., 1999. Effects of habitat fragmentation on Dombeya acutangula (Sterculiaceae), a native tree on La Réunion (Indian Ocean). Biological Conservation 88 43-51.

Gunderson, L., Holling, C.S.E., 2002. Panarchy: understanding transformations in human and natural systems. Island Press, Washington, DC.

Holling, C.S., 1987. Simplifying the complex: the paradigms of ecological function and structure. European Journal of Operational Research 30 139-146. 
INSEE, 2009. Recensement général de la population française. [online] www.insee.fr, accessed 21 October 2009.

Jenkins, M., 2003. Prospects for Biodiversity. Science 302 (5648) 1175 -1177.

Jiggins, J., Röling, N., 2002. Adaptive management: potential and limitations for ecological governance of forests in a context of normative pluriformity. 15-38. In Oglethorpe, J. A. E. (Eds.), Adaptive management: from theory to practice. UICN, Gland, Cambridge.

Kirkpatrick, S., Gelatt, C., Vecchi, M., 1983. Optimization by simulated annealing. Science 220 671-680.

Knight, A. T., Cowling, R. M., Campbell, B.M., 2006. An operationnal model for implementing conservation action. Conservation Biology 20 (2) 408-419.

Lagabrielle, E., Metzger, P., Martignac, C., Lortic, B., Durieux, L., 2007. Les dynamiques d'occupation du sol à La Réunion (1989-2002). M@ppemonde 86 (2) [online] URL: http://mappemonde.mgm.fr/num14/articles/art07205.pdf

Lagabrielle, E., Rouget M., Payet K., Wistebaar N., Durieux L., Baret S., Lombard A., Strasberg D., 2009. Identifying and mapping biodiversity processes for conservation planning in islands: A case study in Réunion Island (Western Indian Ocean). Biological Conservation 142 (7) 1523-1535.

Ligtenberg, A., Wachowicz, M., Bregt, A.K., Beulens, A., Kettenis, D.L., 2004. A design and application of a multi-agent system for simulation of multi-actor spatial planning. Journal of Environmental Management 72 43-55.

Lombard, A.T., Cowling, R.M., Pressey, R.L., Rebelo, A.G., 2003. Effectiveness of land classes as surrogates for species in conservation planning for the Cape Floristic Region. Biological Conservation 112 (1-2) 45-62.

Ludwig, D., 2001. The era of management is over. Ecosystems 4 (8) 758-764.

Margules, C.R., Pressey, R.L., 2000. Systematic conservation planning. Nature 405 243-253.

Maruani, T., Amit-Cohen, I., 2007. Open space planning models: A review of approaches and methods. Landscape and Urban Planning 81 1-13.

Mathevet, R., Bousquet, F., Le Page, C., Antona, M., 2003. Agent-based simulations of interactions between duck population, farming decisions and leasing of hunting rights in the Camargue (Southern France). Ecological Modelling 165 (2-3) 107-126.

Mittermeier, R.A., da Fonseca, G.A.B., Hoffman, M., Pilgrim, J., Brooks, T., Gill, P.R., Mittermeier, C.G., Lamoreux, J., 2005. Hotspots revisited : Earth's biologically richest and most endangered terrestrial ecoregions. CEMEX, Conservation International.

Moilanen, A., Kujala, H., 2008. Zonation spatial conservation planning framework and software v. 2.0, User manual. 
Parker, D.C., Manson, S.M., Janssen, M.A., Hoffmann, M.J., Deadman, P., 2002. Multi-Agent Systems for the Simulation of Land-Use and Land-Cover Change: A Review. Annals of the Association of American Geographers 93 314-337.

Payet, D., Courdier, R., Sébastien, N. , Ralambondrainy, T., 2006. Environment as support for simplification, reuse and integration of processes in spatial MAS, IRI'2006, Hawaii, USA.

Payet, D., David, D. , Sébastien, N., 2007. XELOC: eXtensible Editing Language Of Configuration - To facilitate complex systems configuration edition and reuse, EA2525 LIM/IREMIA Technical Report.

Piaget, J., 1967. Logique et Connaissance scientifique. Paris, Gallimard.

Roberts, C.M., Mcclean, C.J., Veron, J.E.N., Hawkins, J.P., Allen, G.R., Mcallister, D.E., Mittermeier, G.C., Schueler, F.W., Spalding, M., Wells, F., Vynne, C., Werner, T.B., 2002. Marine biodiversity Hotspots and Conservation Priorities for Tropical Reefs. Science, 295 (5558) 1280-1284.

Sarkar, S., Margules, C., 2002. Operationalizing biodiversity for conservation planning. Journal of Biosciences 27(4 (suppl. 2)) 299-308.

Schreinemachers, P., Berger, T., 2006. Land-use decisions in developing countries and their representation in multi-agent systems. Journal of land-use science 1 (1) 2944.

Smit, B., Wandel, J., 2006. Adaptation, adaptive capacity and vulnerability. Global environmental change 16 (3) 282-292.

Smith, R.J., 2004. Conservation Land-Use Zoning (CLUZ) software.

Souchère V., Millair L., Echeverria J., Bousquet F., Le Page C., Etienne M., 2009. Co-constructing with stakeholders a role-playing game to initiate collective management of erosive runoff risks at the watershed scale. Environmental Modelling \& Software doi:10.1016/j.envsoft.2009.03.002 doi:10.1016/j.envsoft.2009.03.002

Strasberg, D., Rouget, M., Richardson, D.M., Baret, S., Dupont, J., Cowling, R.M., 2005. An assessment of habitat diversity, transformation and threats to biodiversity on Réunion Island (Mascarene Islands, Indian Ocean) as a basis for conservation planning. Biodiversity and Conservation 14 (12) 3015-3032.

Termorshuizen, J., Opdama, P, van den Brink, A., 2007. Incorporating ecological sustainability into landscape planning. Landscape and Urban Planning 79 374-384.

Turton, A. R., Hattingh, J., Claassen, M., Roux, D. J., Ashton, P. J., 2007. Towards a model for ecosystem governance: An integrated water resource management example. In: Turton, A. R., Hattingh, J., Claassen, M., Roux, D. J., Ashton, P. J., (Eds.), Governance as a Trialogue: Government-Society-Science in Transition, Springer, Berlin.

van der Valk, A., 2002. The Dutch planning experience. Landscape and Urban Planning 58 (2) 201-210. 
1074 Vejpas C., Bousquet F., Naivinit W., Trébuil G., et N. Srisombat. 2005. Participatory

11075 modeling for managing rainfed lowland rice variety and seed systems in lower

21076 Northeast Thailand: methodology and preliminary findings. 141-163. In: Bousquet, F, 41077 Trébuil G, Hardy B (Eds.), Companion Modeling and Multi-Agent Systems for 51078 Integrated Natural Resource Management in Asia, Cirad and International Rice 61079 Research Institute, Los Baños, Laguna, Philippines.

81080

${ }^{9} 1081$

1082

1083

14

51084

61085

1086

18

191087

1088

31089

Venter, A.K., Breen, M.B., 1998. Partnership forum framework: participative

framework for protected area outreach. Environmental management 22 (6) 803-815.

Verburg, P.H., Schot, P., Dijst, M., Veldkamp, A., 2004. Land-use change modelling: current practices and research priorities. GeoJournal 61 (4) 309-324.

Wallace, K. J., 2003. Confusing means with ends: A manager's reflections on experience in agricultural landscapes of Western Australia. Ecological Management and Restoration 4 (1) 23-28.

Wilson, E.O., Peter, M., 1988. Biodiversity. National Academic Press, Washington DC. 


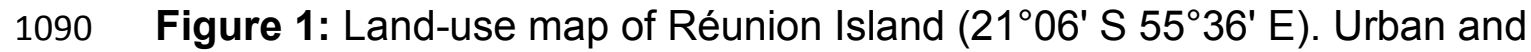
agricultural areas are currently expanding toward the uplands.

4

5

6

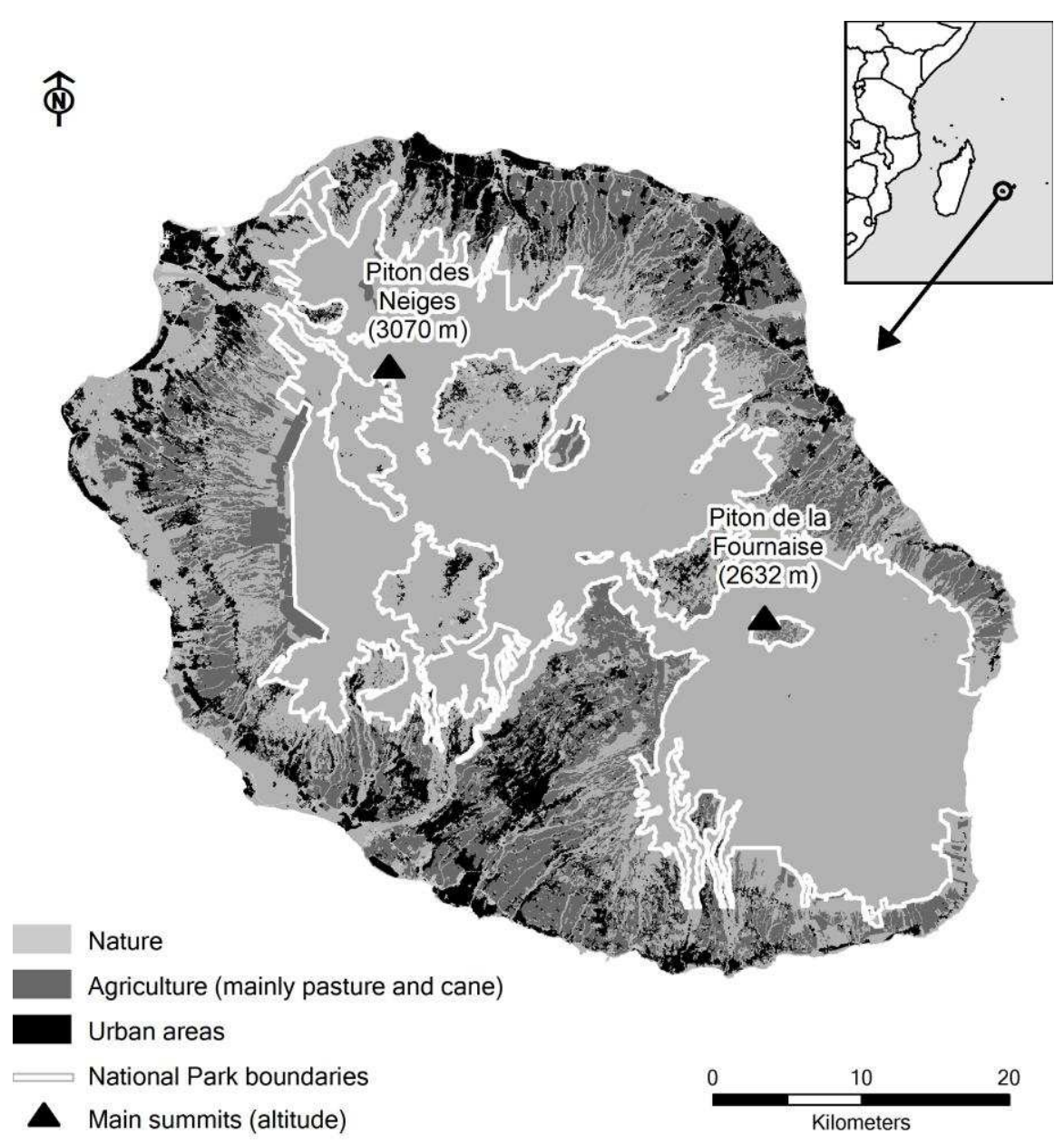


1096

11097

2 1098 41099

Figure 2: Maps showing, a) the transformation status of habitats, b) record data on endemic plants (National Botanical Garden of Mascarin), c) the Spatial Components of Biodiversity Processes (SCBPs) and d) the large scale conservation corridors.

a) Habitats

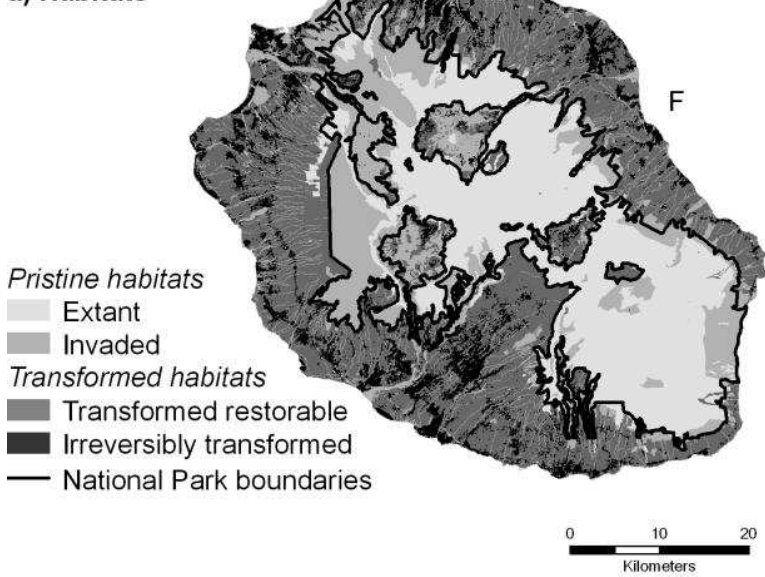

c) Spatial components of biodiversity processes (SCBPs)

SCBPs status

$$
\text { Extent }
$$

Restorable

Lost

— National Park boundaries b) Species data
Endemic plants records Island

— National Park boundaries

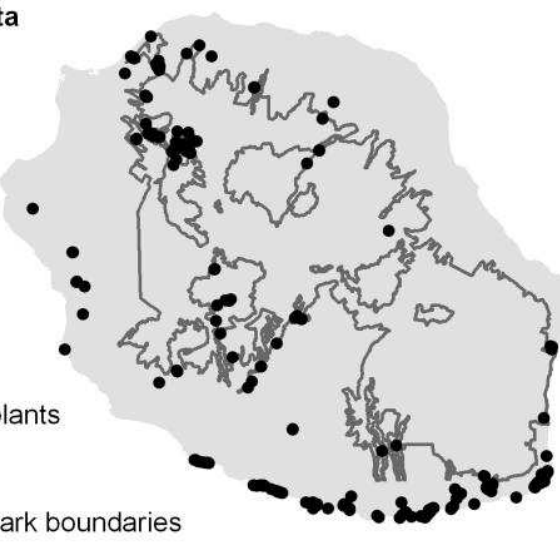

d) Large scale conservation corridors

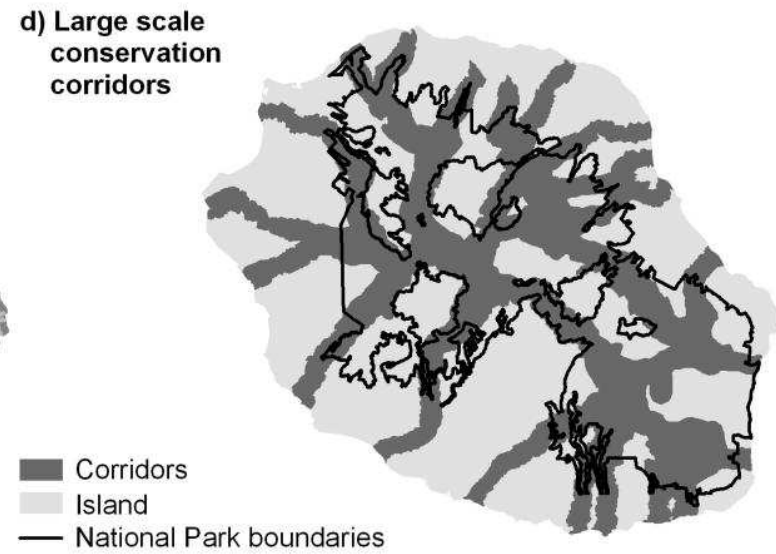

Corridors Island

_ National Park boundaries 
1102

${ }^{1} 1103$

Figure 3: The spatial optimization process embedded in MARXAN selects an optimal network of conservation sites that achieves conservation targets while minimising a set of costs. External design constraints are calculated for each planning unit (costly planning units are to be avoided). The calculation of the Synthetic Index of Conservation Costs is explained in Table 3. Internal design constrains are introduced to limit scattered spatial solutions by minimising the length of boundaries among selected and non selected planning units. $\Sigma$ stands for sum. See Ball and Possingham (2000) for the model equations.

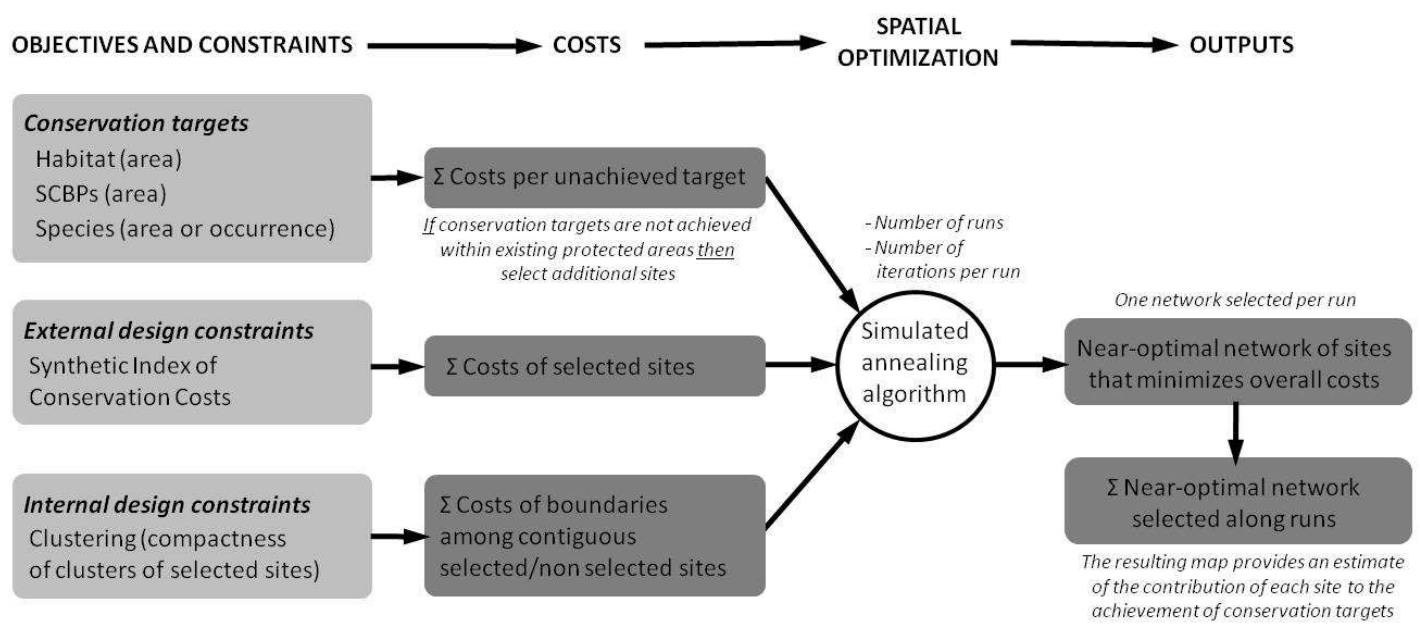


1113 Figure 4: UML class diagram of the land-use simulation model structure. Social 11114 entities are in grey while the white classes correspond to spatial entities. 31115 4

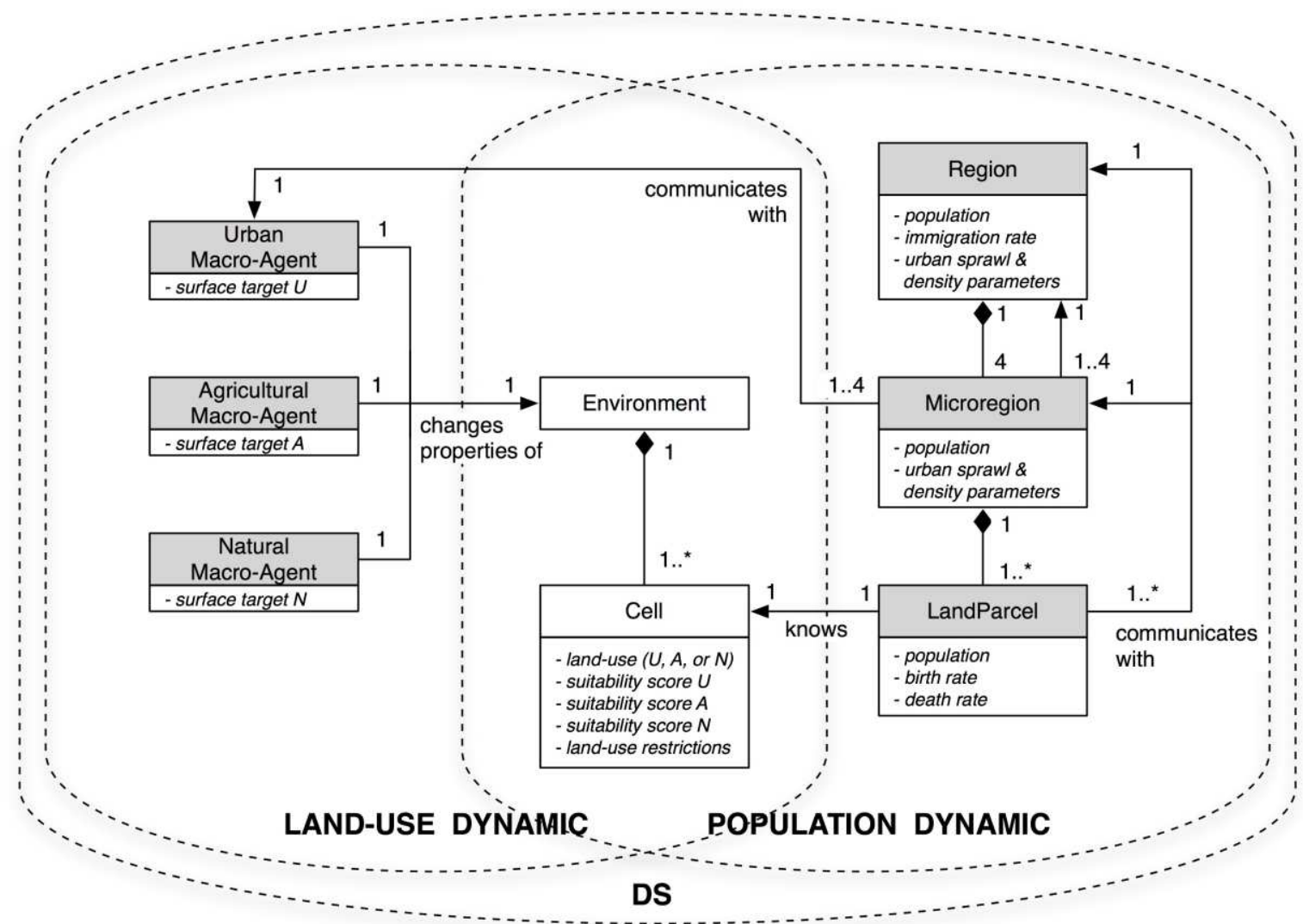


Figure 5: The interface of the land-use simulation model is composed of 4 panels. The Minimap Panel (MP) enables to select and move the visible area of the island. The Control Panel (CP) enables to define simulations parameters, to initialise simulations, and to launch simulations. The View Panel (VP) displays the evolutions of the visible area via a colour graduation that shows the population or the land-use type of the cells. And the Information Panel (IP) displays the information about the system entities that can be selected by clicking on the VP. On the left side is the information on the selected cell, and on the right side is the information on the corresponding land parcel agents.

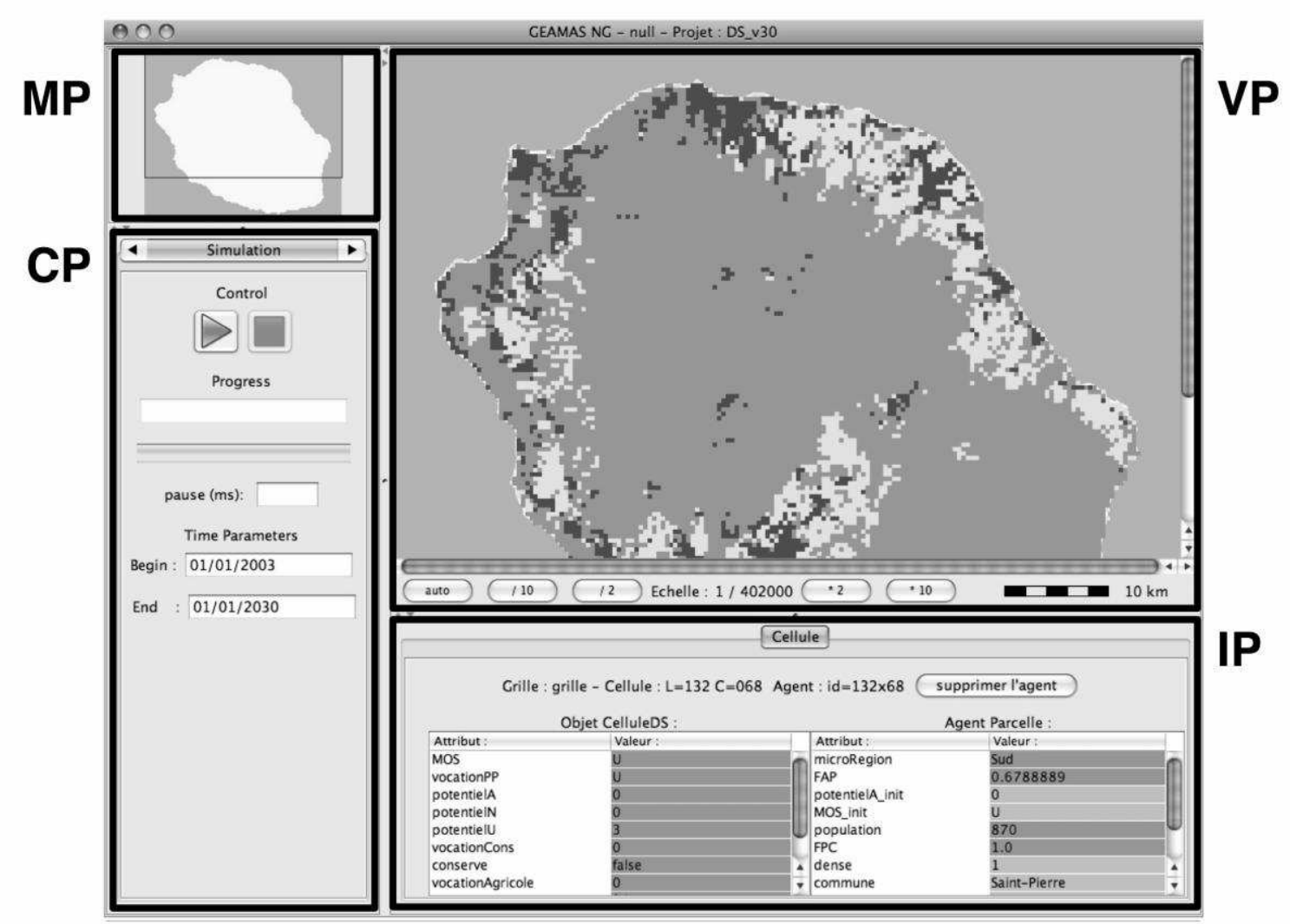


1130

11131

21132

41133 61134

Figure 6: Land-use map obtained by simulation at the horizon 2030 with two of the scenarios simulated for the foresight process of the SAR: the Nature-friendly scenario (a), the Economy-oriented scenario (b) and their respective impacts on biodiversity features compared to an initial state in 2005 (c).

(a) Nature-friendly scenario

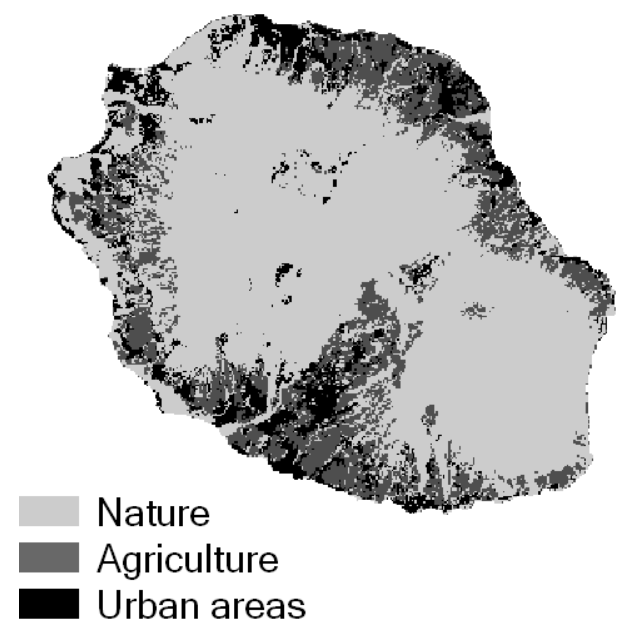

(b) Economy-oriented scenario

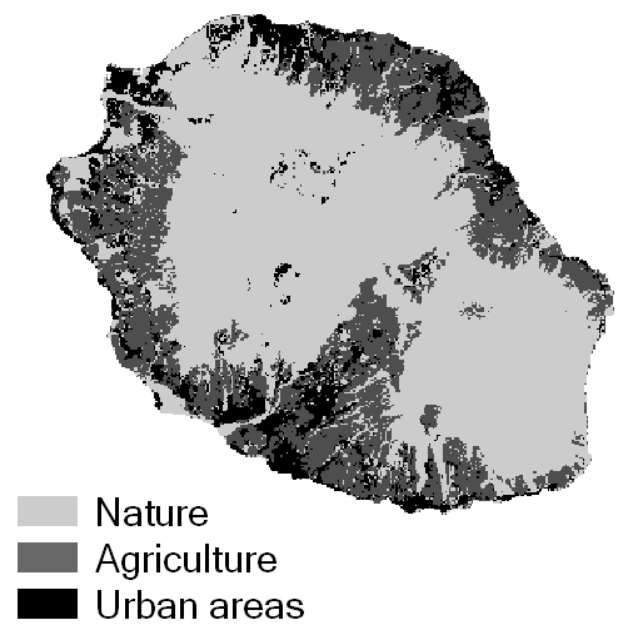

(c) Percentage of loss (surface or occurence) per category of biodiversity feature per scenario (compared to 2005)

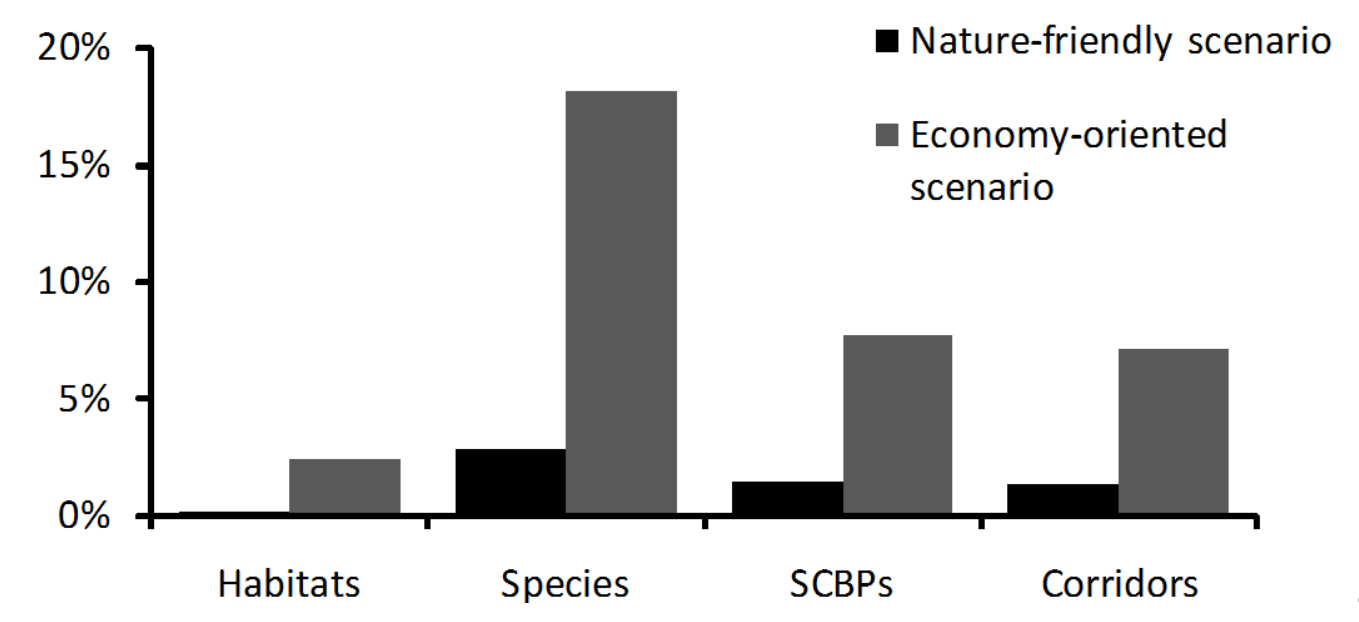


Figure 7: The impact of implementing additional reserves on the satisfaction of the agricultural demand for land (along the Trend scenario) with the current conservation reserve network only (a), when conserving the additional irreplaceable sites identified in the modelling sequence 2 (b) and when adding the large scale conservation corridors (c). The exponential shape of the curves is due to the concomitant conversion of agricultural land by urbanisation in the lowlands.

a) Protected areas (PAs)

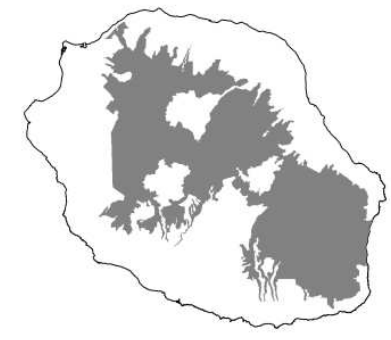

Current conservation sites

Additionnal conservation sites b) PAs + Irreplaceable sites

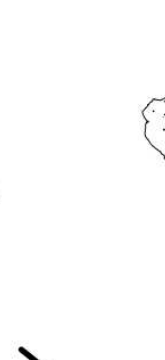

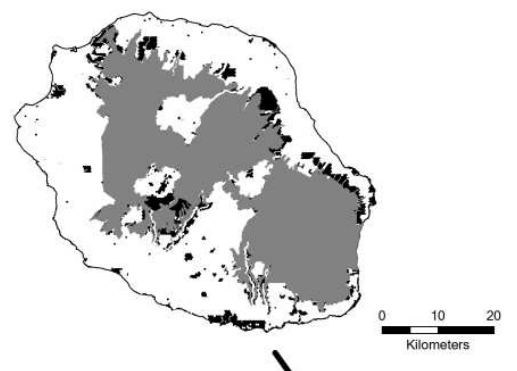

c) PAs + Irreplaceable sites + Corridors

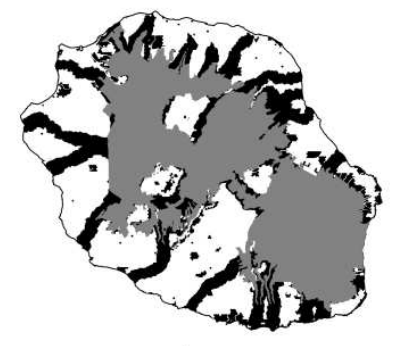


Table 1: Area of ecological habitats grouped per altitude categories, nowadays and before human colonization (Strasberg et al., 2005). Habitat transformation decreases with altitude. In this table, the transformed status category comprises both transformed restorable and irreversibly transformed habitats.

\begin{tabular}{lccc}
\hline $\begin{array}{l}\text { Ecological habitat category } \\
\text { grouped per altitude }\end{array}$ & $\begin{array}{c}\text { Area before human } \\
\text { colonization }\left(\mathrm{km}^{2}\right)\end{array}$ & $\begin{array}{c}\text { Current area } \\
\left(\mathrm{km}^{2}\right)\end{array}$ & $\begin{array}{c}\text { Transformed } \\
(\%)\end{array}$ \\
\hline Recent lava flow & 97 & 95 & 2 \\
Wetlands & 8 & 7 & 12 \\
Subalpine & 205 & 177 & 14 \\
Mountain & 564 & 400 & 29 \\
Submountain & 449 & 210 & 53 \\
Coastal & 14 & 3 & 78 \\
Lowland & 1165 & 115 & 90 \\
Total & 2504 & 1008 & 60 \\
\hline
\end{tabular}


Table 2: Prioritisation of the key challenges as identified in the three alternative scenarios defined for the SAR revision. The list actually used had 13 challenges, but for clarity, this table shows only the 3 first challenges of each of the scenario.

\begin{tabular}{|c|c|c|c|}
\hline Challenges & $\begin{array}{c}\text { Nature } \\
\text { friendly } \\
\text { scenario }\end{array}$ & $\begin{array}{l}\text { Economy- } \\
\text { oriented } \\
\text { scenario }\end{array}$ & $\begin{array}{l}\text { Urbanisation- } \\
\text { oriented } \\
\text { scenario }\end{array}$ \\
\hline \multirow{2}{*}{$\begin{array}{l}\text { Durable management of resources } \\
\text { (water, energy, biodiversity...) } \\
\text { Conservation of natural and agricultural } \\
\text { patrimony and landscapes }\end{array}$} & 1 & & \\
\hline & 2 & & \\
\hline Rationalisation of urban sprawl & 3 & 2 & 2 \\
\hline Social cohesion & & & 3 \\
\hline Housing a million of inhabitant & & & 1 \\
\hline Employment & & 3 & \\
\hline Steady development of the economy & & 1 & \\
\hline
\end{tabular}


Table 3: Components of the Synthetic Index of Conservation Costs (SICC) used to calculate the external design constraints cost in MARXAN. Values for each components rank from 0 to 10 .

\begin{tabular}{|c|c|c|}
\hline SICC component & Rationale & $\begin{array}{l}\text { Value } \\
\text { Min - max }\end{array}$ \\
\hline Implementation cost & $\begin{array}{l}\text { Public-owned areas are cheaper for implementing reserves } \\
\text { than privately-owned areas. Although they encapsulate } \\
\text { private land, extant statutory reserves were considered as } \\
\text { publicly-owned areas owing to their management regime. }\end{array}$ & $0-10$ \\
\hline $\begin{array}{l}\text { Invasive plants } \\
\text { control cost }\end{array}$ & $\begin{array}{l}\text { Alien plants control implicates major costs for conservation in } \\
\text { insular regions (Baret et al.2006). This cost is minimum in } \\
\text { pristine habitats and maximum in invaded habitats. }\end{array}$ & $0-10$ \\
\hline Restoration cost & $\begin{array}{l}\text { The restoration of transformed ecosystems involves massive } \\
\text { investments in addition to other conservation costs. } \\
\text { Restoration cost is low in pristine habitats and maximum in } \\
\text { irreversibly transformed habitats. }\end{array}$ & $0-10$ \\
\hline $\begin{array}{l}\text { Conversion pressure } \\
\text { cost }\end{array}$ & $\begin{array}{l}\text { Conversion pressure is the probability of habitat conversion } \\
\text { by urbanisation, agriculture and invasive plants in each } \\
\text { planning unit. This cost varies from } 0 \text { (null probability) to } 10 \\
\text { (high probability). }\end{array}$ & $0-10$ \\
\hline
\end{tabular}


Table 4: Description of the four land-use scenarios defined by the SAR revision participants and their transcription in the land-use simulation model.

\begin{tabular}{|c|c|c|c|}
\hline Scenario & Motto & Main characteristics & Transcription in DS \\
\hline Trend & $\begin{array}{l}\text { The 'Let it be- } \\
\text { island' } \\
\text { Inaction, weak } \\
\text { organisation } \\
\text { and socio- } \\
\text { economic crisis }\end{array}$ & $\begin{array}{l}\text { Economy centred on the } \\
\text { internal market } \\
\text { Unachieved targets for } \\
\text { housing and agriculture } \\
\text { (socio-economic crisis) } \\
\text { Uncontrolled urban sprawl } \\
\text { on agricultural land and } \\
\text { pristine habitats } \\
\text { Protection of biodiversity in } \\
\text { statutory reserves only. } \\
\text { Increasing costs for the } \\
\text { management of renewable } \\
\text { resources. }\end{array}$ & $\begin{array}{l}\text { Population still } \\
\text { accumulating rather in the } \\
\text { southern and western parts } \\
\text { of the Island } \\
\text { Low ratio of urban } \\
\text { densification } \\
\text { The agricultural sector } \\
\text { targets a stable surface } \\
\text { Only the current statutory } \\
\text { reserve network is } \\
\text { preserved }\end{array}$ \\
\hline $\begin{array}{l}\text { Nature- } \\
\text { friendly }\end{array}$ & $\begin{array}{l}\text { The 'Green } \\
\text { island' } \\
\text { Attractive } \\
\text { island }\end{array}$ & $\begin{array}{l}\text { Economy open to the } \\
\text { external market thanks to its } \\
\text { attraction for tourism } \\
\text { Polarised densification of } \\
\text { urban areas } \\
\text { Protection of agricultural } \\
\text { lands } \\
\text { Protection of biodiversity in } \\
\text { statutory reserves only }\end{array}$ & $\begin{array}{l}\text { Population accumulating } \\
\text { rather in the eastern and the } \\
\text { northern part of the Island. } \\
\text { Systematic high urban } \\
\text { densification } \\
\text { Agricultural areas are } \\
\text { forbidden for urbanisation } \\
\text { Only the current statutory } \\
\text { reserve network is } \\
\text { preserved }\end{array}$ \\
\hline $\begin{array}{l}\text { Economy- } \\
\text { oriented }\end{array}$ & $\begin{array}{l}\text { The } \\
\text { 'competitive } \\
\text { island' } \\
\text { Expansion of } \\
\text { urbanisation } \\
\text { and agriculture }\end{array}$ & $\begin{array}{l}\text { Economy centred on the } \\
\text { internal market } \\
\text { Polarised densification of } \\
\text { urban areas } \\
\text { Large expansion of } \\
\text { agriculture on pristine } \\
\text { habitats } \\
\text { Protection of biodiversity in } \\
\text { statutory reserves only. }\end{array}$ & $\begin{array}{l}\text { Population still } \\
\text { accumulating rather in the } \\
\text { southern and western parts } \\
\text { of the Island } \\
\text { Systematic high urban } \\
\text { densification } \\
\text { The agricultural sector } \\
\text { targets a } 25 \% \text { surface } \\
\text { increase } \\
\text { Agricultural areas are } \\
\text { forbidden for urbanisation } \\
\text { Only the current statutory } \\
\text { reserve network is } \\
\text { preserved }\end{array}$ \\
\hline $\begin{array}{l}\text { Urbanisatio } \\
\text { n-oriented }\end{array}$ & $\begin{array}{l}\text { The 'City- } \\
\text { island', } \\
\text { Ravenous } \\
\text { urbanisation } \\
\text { and spatial } \\
\text { compensations } \\
\text { for agriculture }\end{array}$ & $\begin{array}{l}\text { Economy centred on the } \\
\text { internal market } \\
\text { Polarised urban densification } \\
\text { and urban sprawl on } \\
\text { agricultural lands and } \\
\text { pristine habitats } \\
\text { Protection of biodiversity in } \\
\text { statutory reserves only }\end{array}$ & $\begin{array}{l}\text { Population still } \\
\text { accumulating rather in the } \\
\text { southern and western parts } \\
\text { of the Island } \\
\text { Slightly higher densification } \\
\text { rates } \\
\text { The agricultural sector } \\
\text { targets a } 5 \% \text { surface } \\
\text { increase }\end{array}$ \\
\hline
\end{tabular}


Only the current statutory 


\section{市}

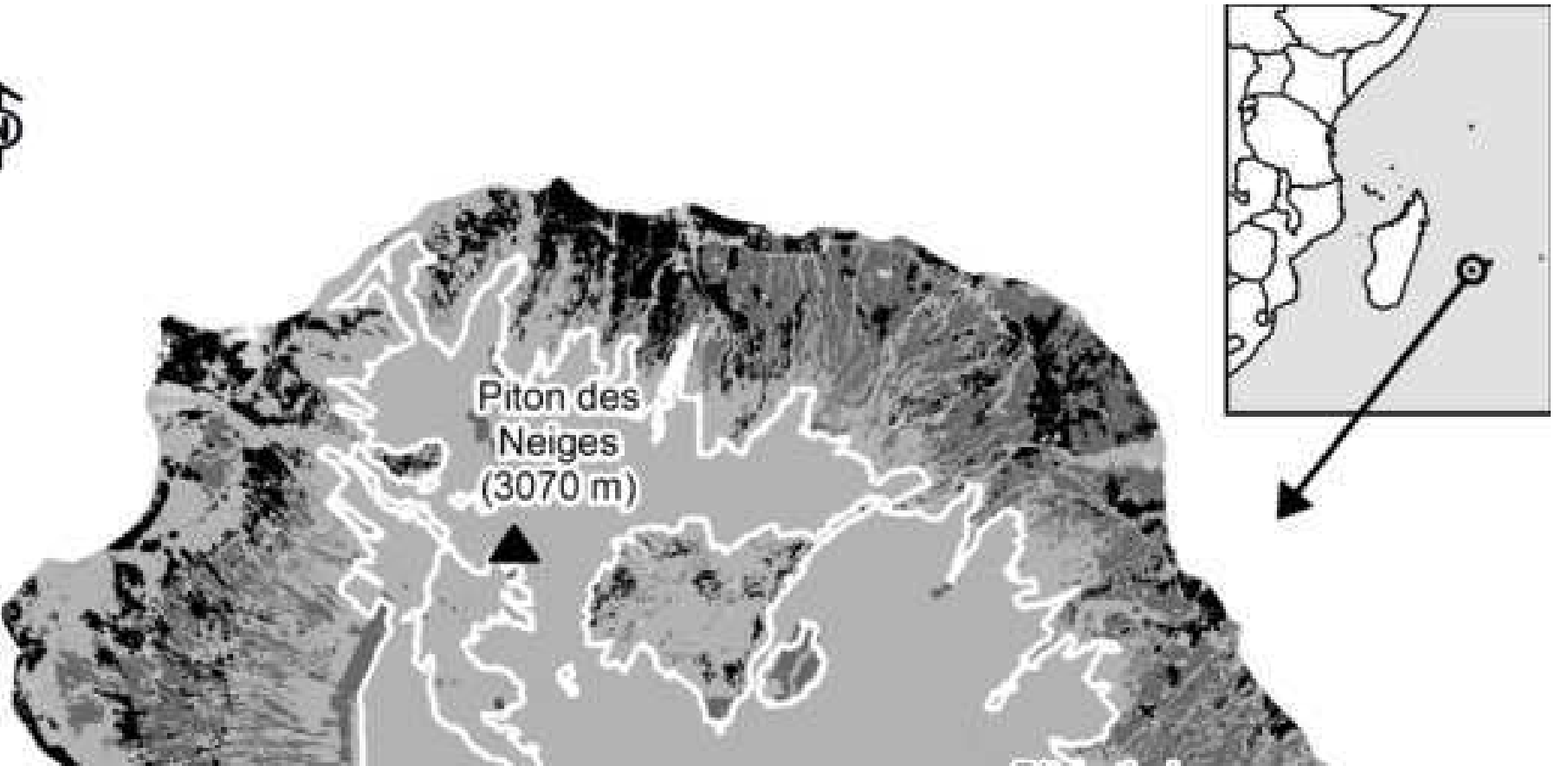

Nature

Agriculture (mainly pasture and cane)

Urban areas

National Park boundaries

0

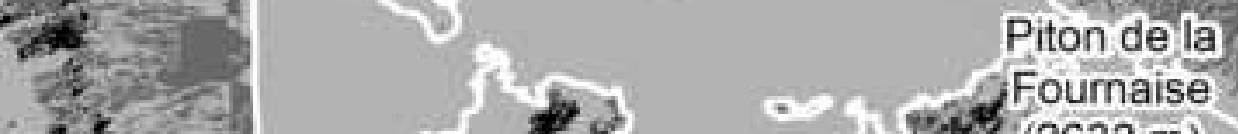

Q

$1, \frac{5}{3}$

3

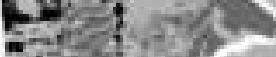

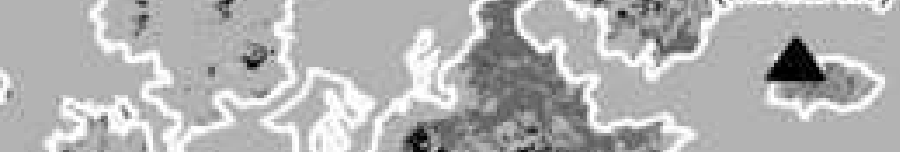

(1)

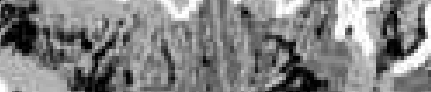

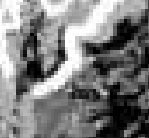

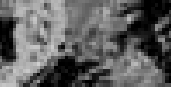

$(2632 \mathrm{~m})$
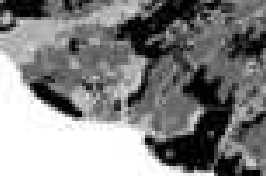

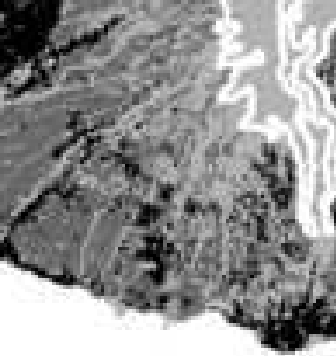
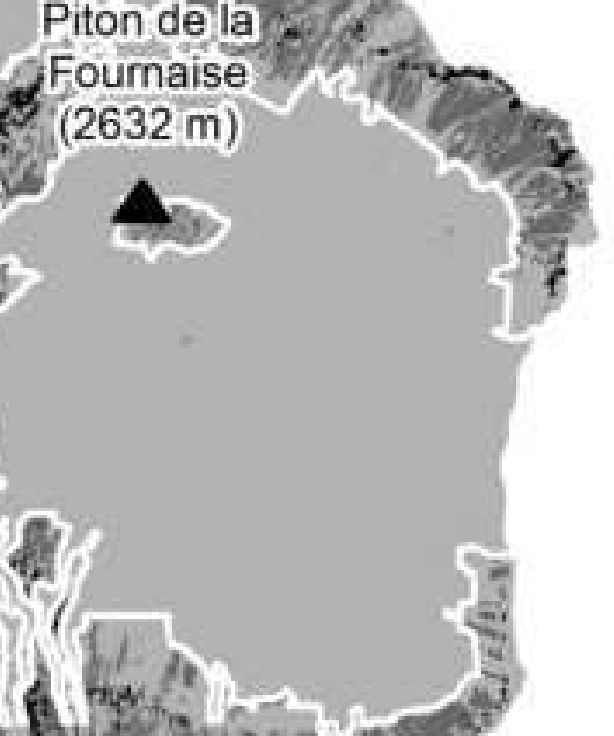

Main summits (altitude)

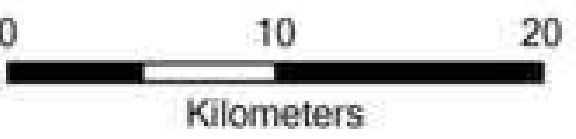


a) Habitats

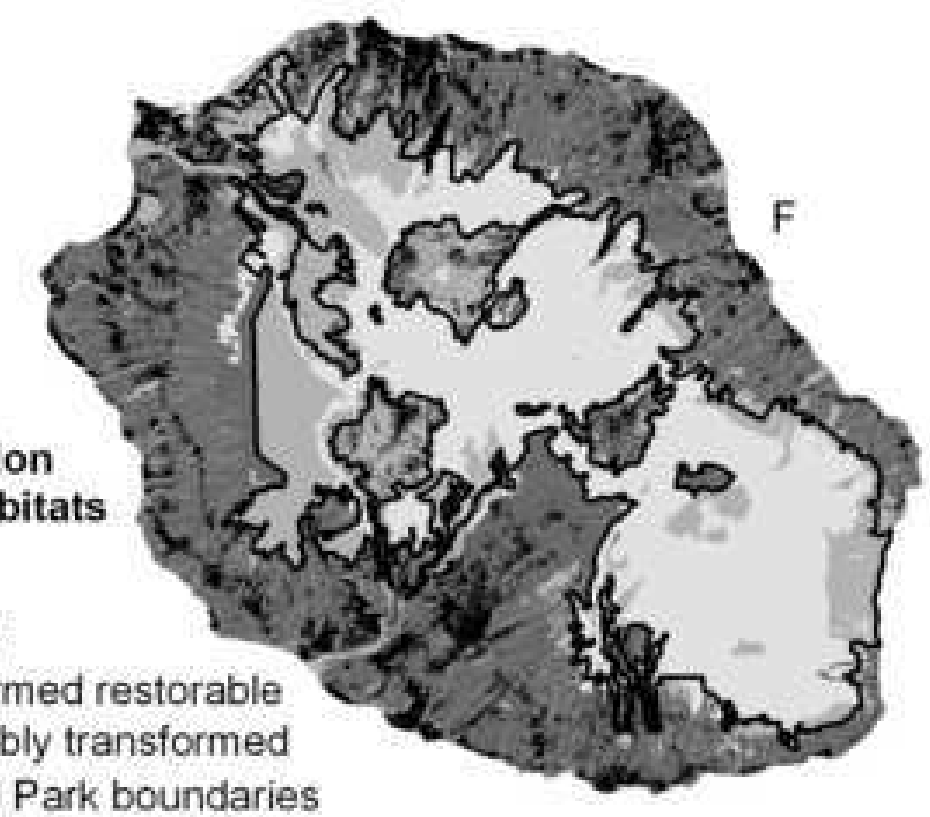

Transfornation status of habitats

\section{Extant}

- Invaded

- Transformed restorable

Irreversibly transformed

- National Park boundaries

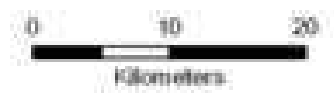

c) Spatial components of biodiversity processes (SCBPs)

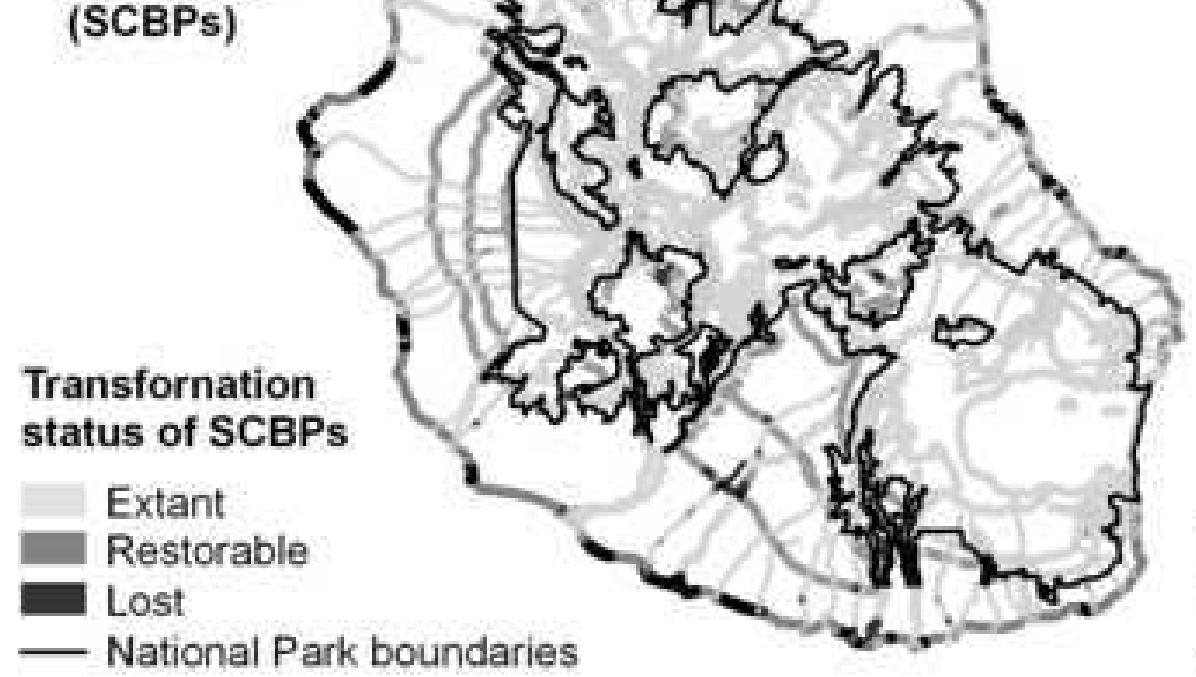

- National Park boundaries.

- Endemic plants
Corridors

Island

b) Species data records

Island

- National Park boundaries

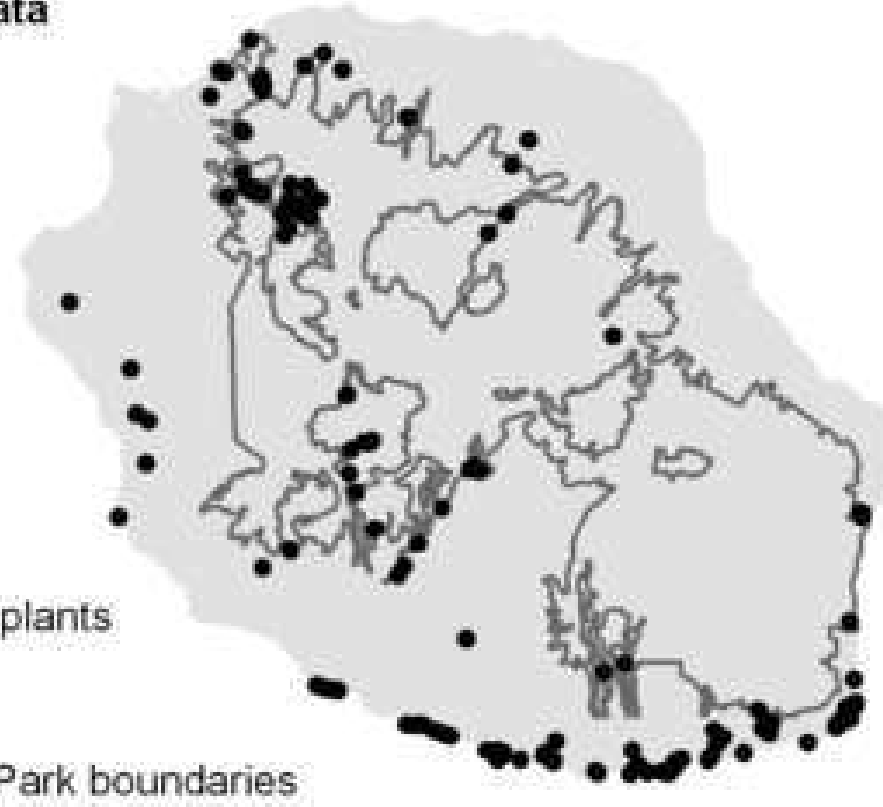

d) Large scale conservation corridors

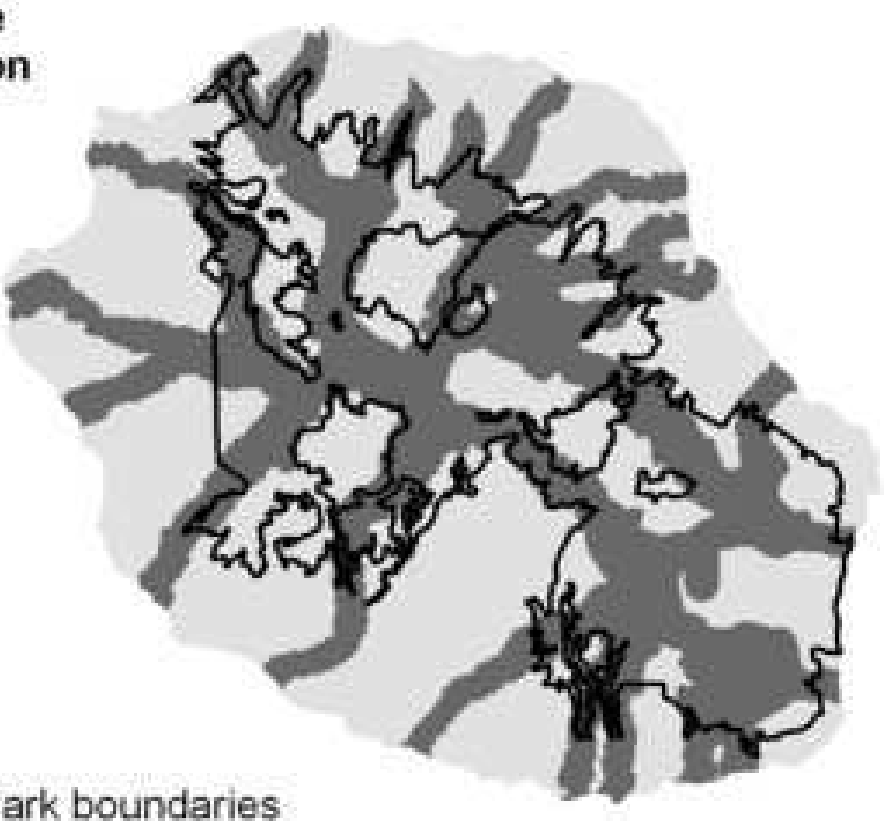


Click here to download high resolution image

\section{OBJECTIVES AND CONSTRAINTS}

\section{Conservation targets \\ Habitat (area) \\ SCBPs (area) \\ Species (area or occurrence)}

\section{External design constraints}

Syntheticindex of

Conservation Costs

Internal design constraints

Clustering (compactness

of clusters of selected sites)

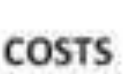

SPATIAL OPTIMIZATION

OUTPUTS

cosTs

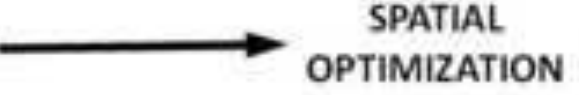

$\Sigma$ Costs per unachieved target

If conservation torgets ore not achieved within existing protected areas then select additional sites

Number of

terations per run

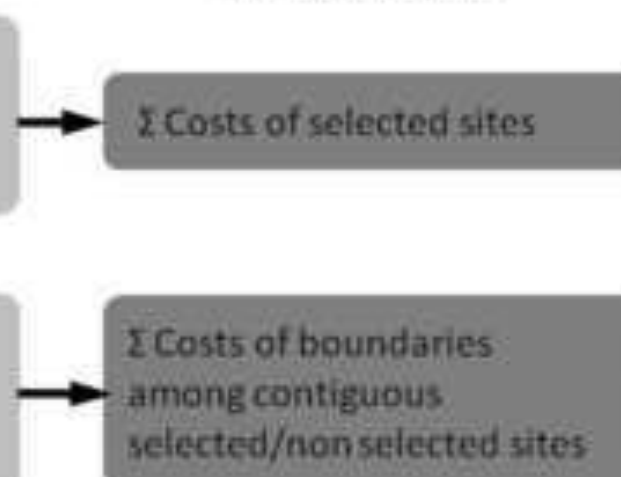

Ore nefworksolisted per rim

Near-optimal network of sites that minimizes overallcosts

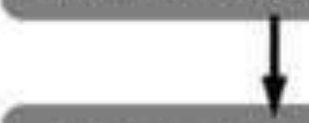

ENear-optimal network selected along runs

The ressining map provides an estanate of the contribution of each site to the achievement of conservotion targets 


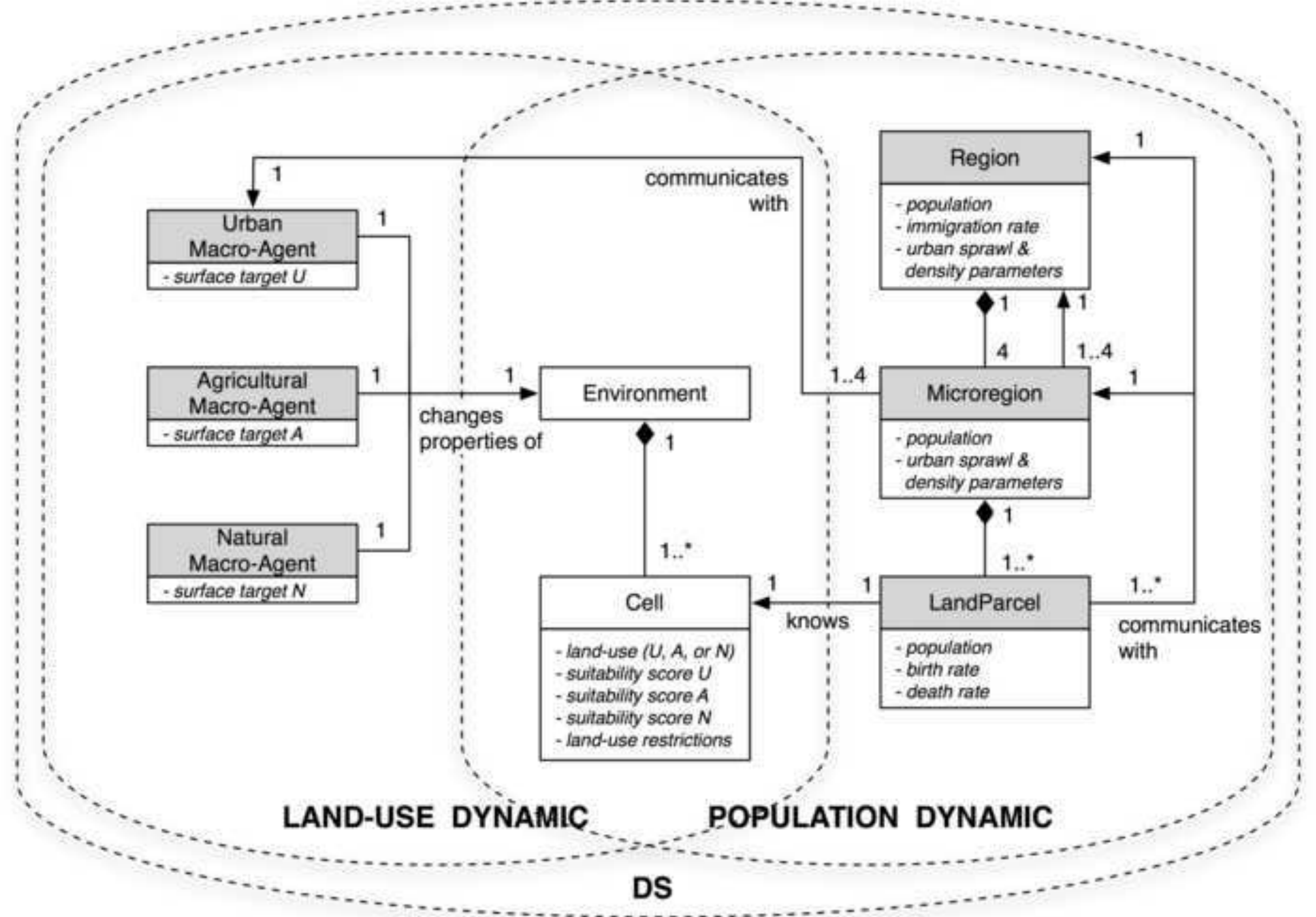


Click here to download high resolution image

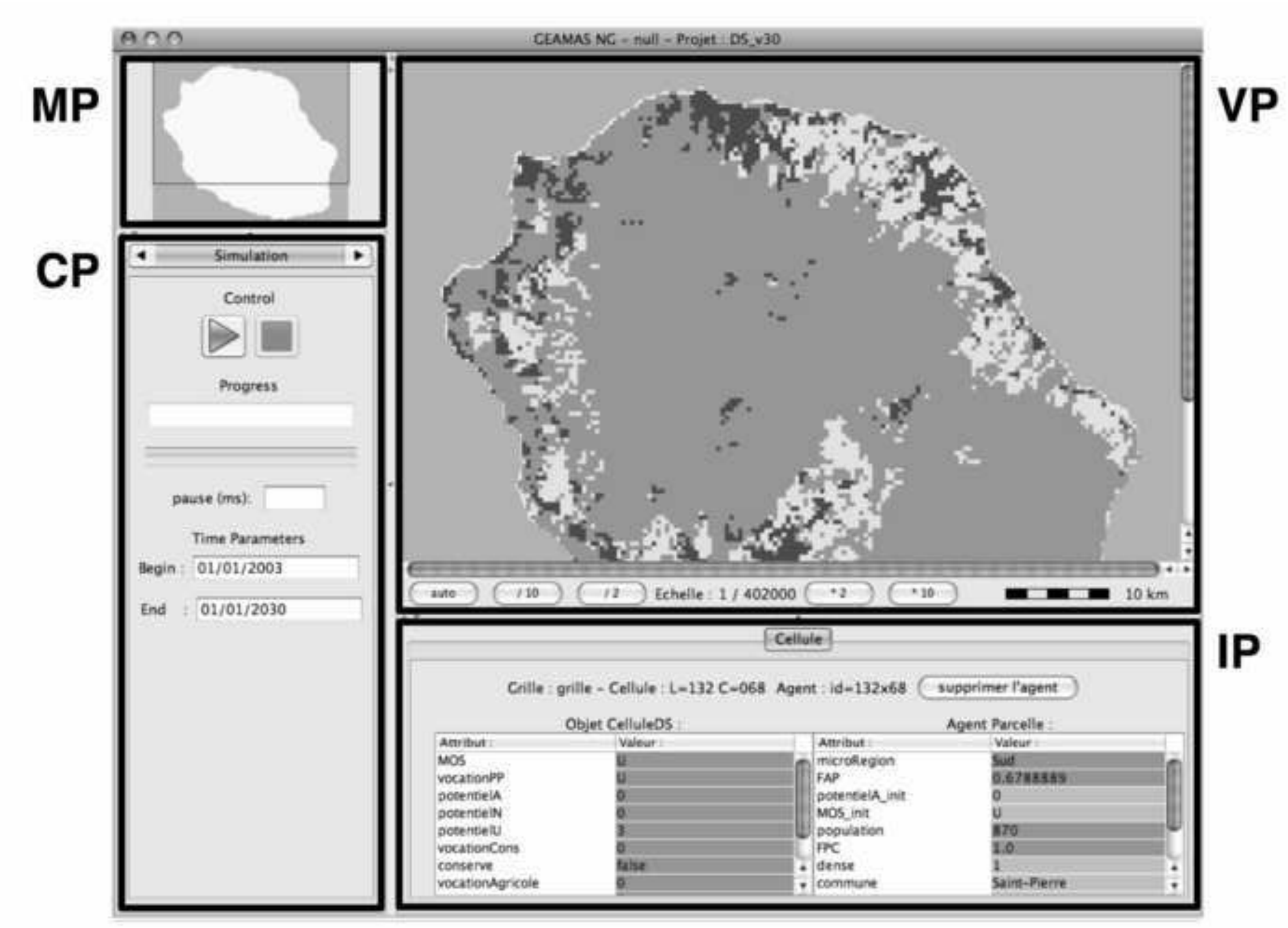

(1)

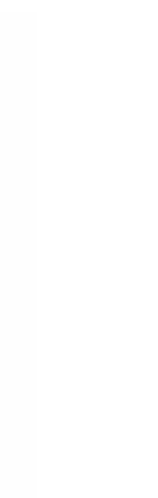

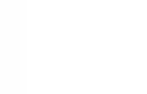


(a) Nature-friendly scenario

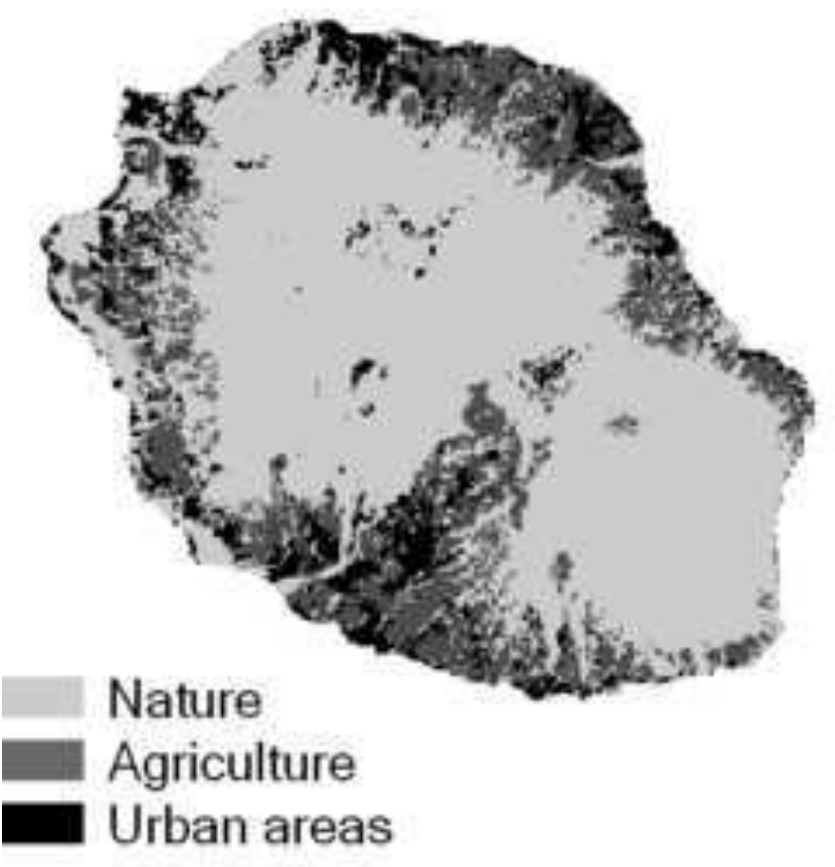

(b) Economy-oriented scenario

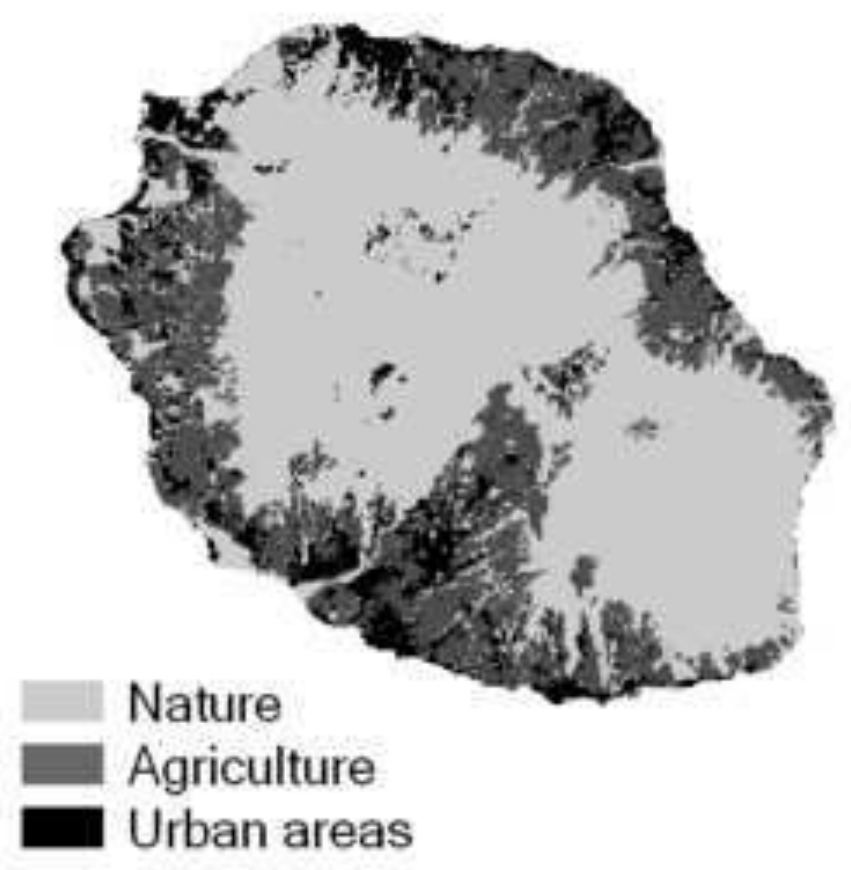

(c) Percentage of loss (surface or occurence) per category of biodiversity feature per scenario (compared to 2005)

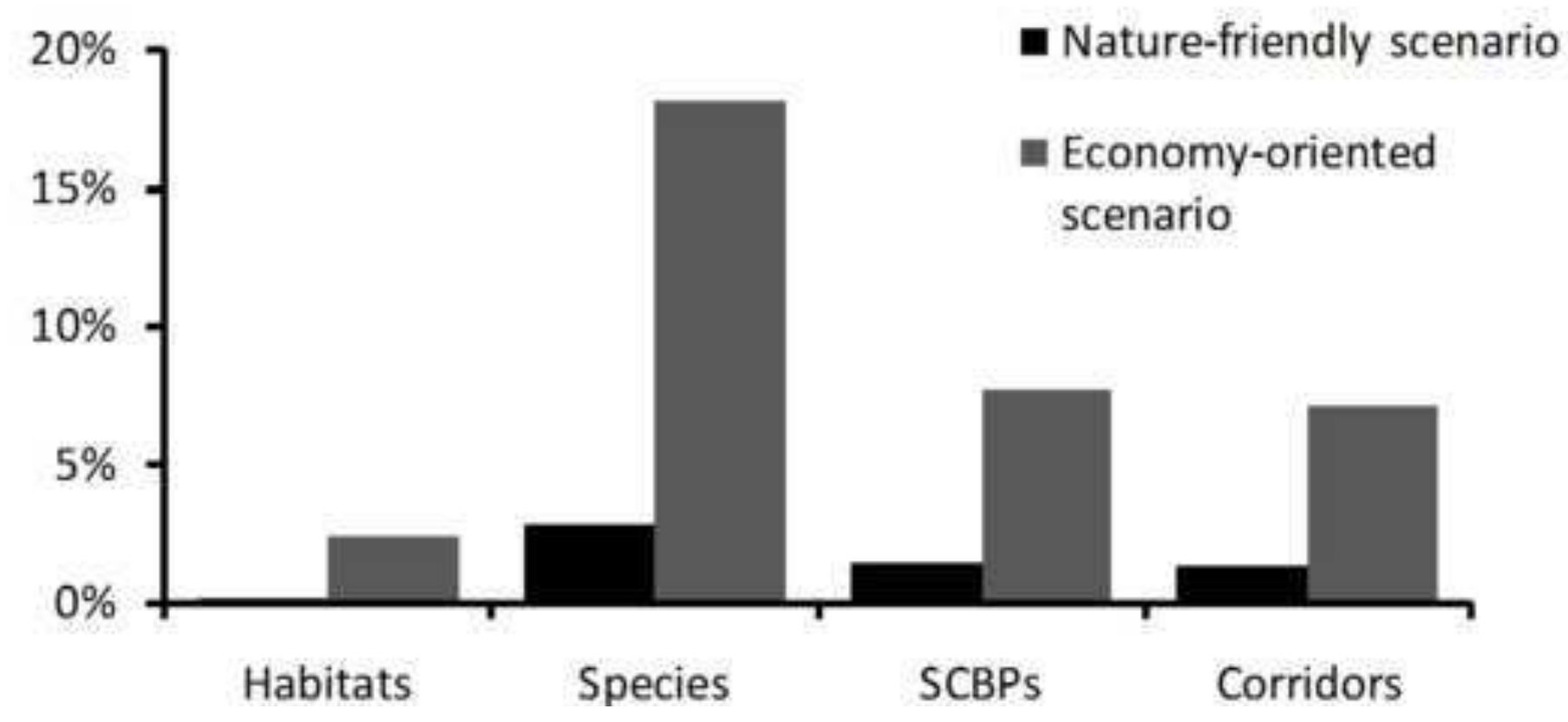


Click here to download high resolution image

a) Protected areas (PAs)

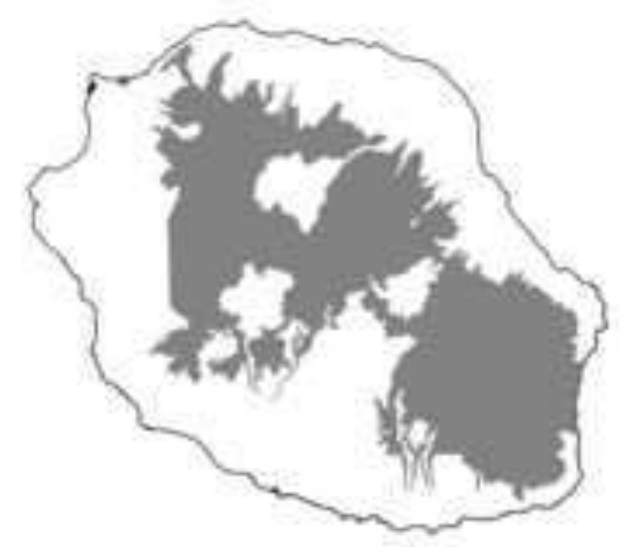

Current conservation sites

additionnal conservation sites b) PAs + Irreplaceable sites
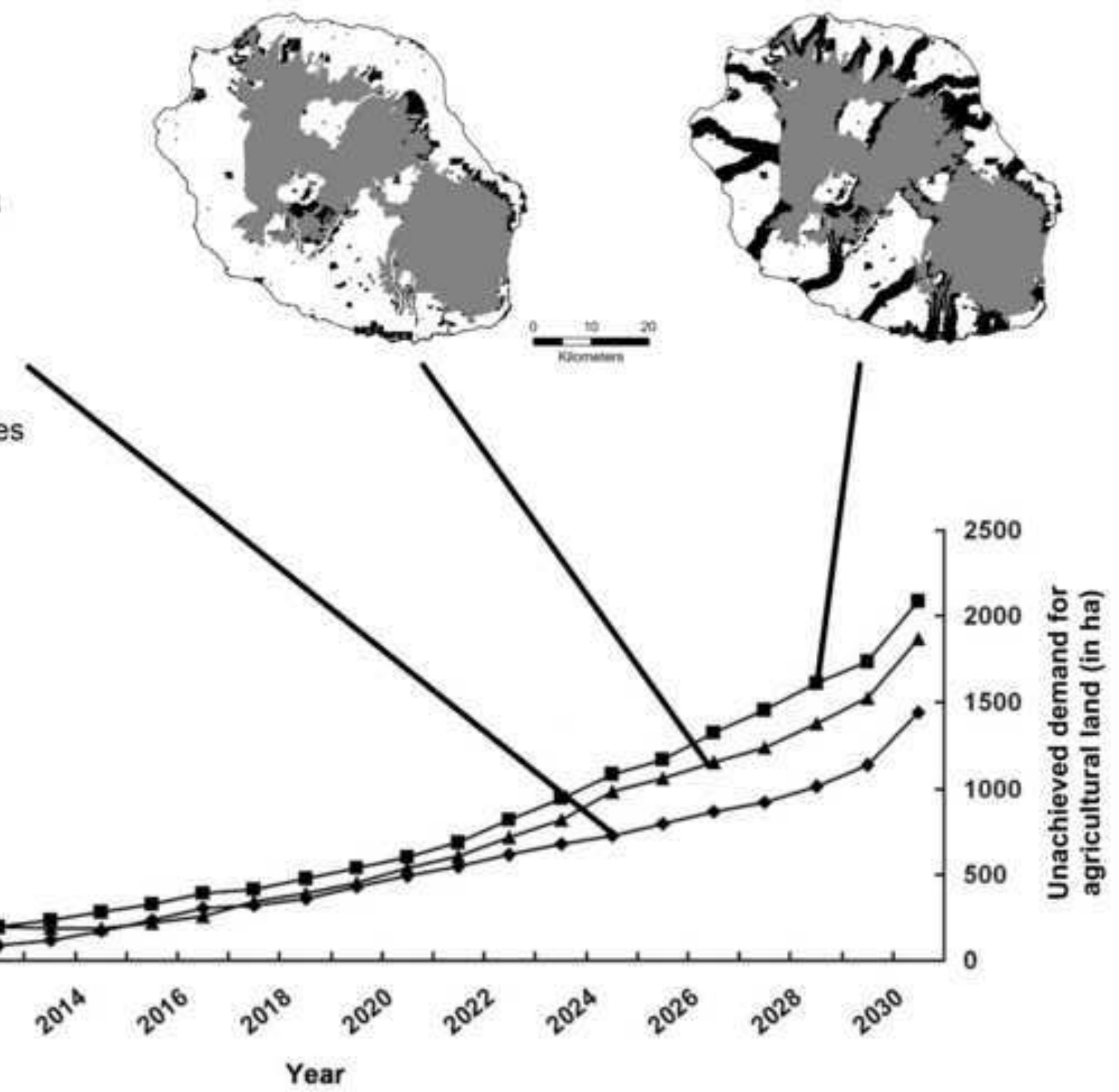

c) PAs + Irreplaceable sites + Corridors 
Table 1: Area of ecological habitats grouped per altitude categories, nowadays and before human colonization (Strasberg et al., 2005). Habitat transformation decreases with altitude. In this table, the transformed status category comprises both transformed restorable and irreversibly transformed habitats.

\begin{tabular}{lccc}
\hline $\begin{array}{l}\text { Ecological habitat category } \\
\text { grouped per altitude }\end{array}$ & $\begin{array}{c}\text { Area before human } \\
\text { colonization }\left(\mathrm{km}^{2}\right)\end{array}$ & $\begin{array}{c}\text { Current area } \\
\left(\mathrm{km}^{2}\right)\end{array}$ & $\begin{array}{c}\text { Transformed } \\
(\%)\end{array}$ \\
\hline Recent lava flow & 97 & 95 & 2 \\
Wetlands & 8 & 7 & 12 \\
Subalpine & 205 & 177 & 14 \\
Mountain & 564 & 400 & 29 \\
Submountain & 449 & 210 & 53 \\
Coastal & 14 & 3 & 78 \\
Lowland & 1165 & 115 & 90 \\
Total & 2504 & 1008 & 60 \\
\hline
\end{tabular}


Table 2: Prioritisation of the key challenges as identified in the three alternative scenarios defined for the SAR revision. The list actually used had 13 challenges, but for clarity, this table shows only the 3 first challenges of each of the scenario.

\begin{tabular}{llll}
\hline Challenges & $\begin{array}{c}\text { Nature } \\
\text { friendly } \\
\text { scenario }\end{array}$ & $\begin{array}{c}\text { Economy- } \\
\text { oriented } \\
\text { scenario }\end{array}$ & $\begin{array}{c}\text { Urbanisation- } \\
\text { oriented } \\
\text { scenario }\end{array}$ \\
\hline $\begin{array}{l}\text { Durable management of resources } \\
\text { (water, energy, biodiversity...) }\end{array}$ & 1 & & \\
$\begin{array}{l}\text { Conservation of natural and agricultural } \\
\text { patrimony and landscapes } \\
\text { Rationalisation of urban sprawl }\end{array}$ & $\mathbf{2}$ & $\mathbf{2}$ & $\mathbf{2}$ \\
$\begin{array}{l}\text { Social cohesion } \\
\text { Housing a million of inhabitant }\end{array}$ & & 3 & 1 \\
\hline $\begin{array}{l}\text { Employment } \\
\text { Steady development of the economy }\end{array}$ & 3 & 1 \\
\hline
\end{tabular}


Table 3: Components of the Synthetic Index of Conservation Costs (SICC) used to calculate the external design constraints cost in MARXAN. Values for each components rank from 0 to 10 .

\begin{tabular}{llc}
\hline SICC component & Rationale & $\begin{array}{l}\text { Value } \\
\text { Min - max }\end{array}$ \\
\hline Implementation cost & $\begin{array}{l}\text { Public-owned areas are cheaper for implementing reserves } \\
\text { than privately-owned areas. Although they encapsulate } \\
\text { private land, extant statutory reserves were considered as } \\
\text { publicly-owned areas owing to their management regime. }\end{array}$ & 0 - 10 \\
$\begin{array}{ll}\text { Invasive plants } \\
\text { control cost }\end{array}$ & $\begin{array}{l}\text { Alien plants control implicates major costs for conservation in } \\
\text { insular regions (Baret et al.2006). This cost is minimum in } \\
\text { pristine habitats and maximum in invaded habitats. }\end{array}$ & 0 - 10 \\
Restoration cost & $\begin{array}{l}\text { The restoration of transformed ecosystems involves massive } \\
\text { investments in addition to other conservation costs. }\end{array}$ & $0-10$ \\
& $\begin{array}{l}\text { Restoration cost is low in pristine habitats and maximum in } \\
\text { irreversibly transformed habitats. }\end{array}$ & \\
\hline $\begin{array}{l}\text { Conversion pressure } \\
\text { cost }\end{array}$ & $\begin{array}{l}\text { Conversion pressure is the probability of habitat conversion } \\
\text { by urbanisation, agriculture and invasive plants in each } \\
\text { planning unit. This cost varies from 0 (null probability) to 10 } \\
\text { (high probability). }\end{array}$ & 0 \\
\hline
\end{tabular}


Table 4: Description of the four land-use scenarios defined by the SAR revision participants and their transcription in the land-use simulation model.

\begin{tabular}{|c|c|c|c|}
\hline Scenario & Motto & Main characteristics & Transcription in DS \\
\hline Trend & $\begin{array}{l}\text { The 'Let it be- } \\
\text { island' } \\
\text { Inaction, weak } \\
\text { organisation } \\
\text { and socio- } \\
\text { economic crisis }\end{array}$ & $\begin{array}{l}\text { Economy centred on the } \\
\text { internal market } \\
\text { Unachieved targets for } \\
\text { housing and agriculture } \\
\text { (socio-economic crisis) } \\
\text { Uncontrolled urban sprawl } \\
\text { on agricultural land and } \\
\text { pristine habitats } \\
\text { Protection of biodiversity in } \\
\text { statutory reserves only. } \\
\text { Increasing costs for the } \\
\text { management of renewable } \\
\text { resources. }\end{array}$ & $\begin{array}{l}\text { Population still } \\
\text { accumulating rather in the } \\
\text { southern and western parts } \\
\text { of the Island } \\
\text { Low ratio of urban } \\
\text { densification } \\
\text { The agricultural sector } \\
\text { targets a stable surface } \\
\text { Only the current statutory } \\
\text { reserve network is } \\
\text { preserved }\end{array}$ \\
\hline $\begin{array}{l}\text { Nature- } \\
\text { friendly }\end{array}$ & $\begin{array}{l}\text { The 'Green } \\
\text { island' } \\
\text { Attractive } \\
\text { island }\end{array}$ & $\begin{array}{l}\text { Economy open to the } \\
\text { external market thanks to its } \\
\text { attraction for tourism } \\
\text { Polarised densification of } \\
\text { urban areas } \\
\text { Protection of agricultural } \\
\text { lands } \\
\text { Protection of biodiversity in } \\
\text { statutory reserves only }\end{array}$ & $\begin{array}{l}\text { Population accumulating } \\
\text { rather in the eastern and the } \\
\text { northern part of the Island. } \\
\text { Systematic high urban } \\
\text { densification } \\
\text { Agricultural areas are } \\
\text { forbidden for urbanisation } \\
\text { Only the current statutory } \\
\text { reserve network is } \\
\text { preserved }\end{array}$ \\
\hline $\begin{array}{l}\text { Economy- } \\
\text { oriented }\end{array}$ & $\begin{array}{l}\text { The } \\
\text { 'competitive } \\
\text { island' } \\
\text { Expansion of } \\
\text { urbanisation } \\
\text { and agriculture }\end{array}$ & $\begin{array}{l}\text { Economy centred on the } \\
\text { internal market } \\
\text { Polarised densification of } \\
\text { urban areas } \\
\text { Large expansion of } \\
\text { agriculture on pristine } \\
\text { habitats } \\
\text { Protection of biodiversity in } \\
\text { statutory reserves only. }\end{array}$ & $\begin{array}{l}\text { Population still } \\
\text { accumulating rather in the } \\
\text { southern and western parts } \\
\text { of the Island } \\
\text { Systematic high urban } \\
\text { densification } \\
\text { The agricultural sector } \\
\text { targets a } 25 \% \text { surface } \\
\text { increase } \\
\text { Agricultural areas are } \\
\text { forbidden for urbanisation } \\
\text { Only the current statutory } \\
\text { reserve network is } \\
\text { preserved }\end{array}$ \\
\hline $\begin{array}{l}\text { Urbanisatio } \\
\text { n-oriented }\end{array}$ & $\begin{array}{l}\text { The 'City- } \\
\text { island', } \\
\text { Ravenous } \\
\text { urbanisation } \\
\text { and spatial } \\
\text { compensations } \\
\text { for agriculture }\end{array}$ & $\begin{array}{l}\text { Economy centred on the } \\
\text { internal market } \\
\text { Polarised urban densification } \\
\text { and urban sprawl on } \\
\text { agricultural lands and } \\
\text { pristine habitats } \\
\text { Protection of biodiversity in } \\
\text { statutory reserves only }\end{array}$ & $\begin{array}{l}\text { Population still } \\
\text { accumulating rather in the } \\
\text { southern and western parts } \\
\text { of the Island } \\
\text { Slightly higher densification } \\
\text { rates } \\
\text { The agricultural sector } \\
\text { targets a } 5 \% \text { surface } \\
\text { increase }\end{array}$ \\
\hline
\end{tabular}


Only the current statutory reserve network is

preserved 


\section{Andrew Knight}

Department of Conservation Ecology \& Entomology

Private Bag X1

Matieland 7602

South Africa

phone: $+27(0) 218084532$

fax: +27 (0)21 8084807

E-mail: tawnyfrogmouth@gmail.com

\section{Pr. Richard Cowling}

Department of Botany

Nelson Mandela Metropolitan University

PO Box 77000

Port Elizabeth 6031, South Africa

Tel: +27 (042) 2980259 (H) Fax: +27 (042) 2980259 (H)

E-mail: richard.cowling@nmmu.ac.za

\section{Raphael Mathevet}

Centre d'Ecologie Fonctionnelle et Evolutive CEFE CNRS UMR 5175 1919 Route de Mende

34293 - Montpellier Cedex 5

E-mail: raphael.mathevet@cefe.cnrs.fr

\section{Amanda Lombard}

Dr A.T. Lombard

Botany Department, Nelson Mandela Metropolitan University, and

Marine Biology Research Centre, University of Cape Town, South Africa.

E-mail: gemsbok@mweb.co.za 